\title{
Use of Mass Spectrometry to Determine the Diversity of Toxins Produced by Gambierdiscus and Fukuyoa Species from Balearic Islands and Crete (Mediterranean Sea) and the Canary Islands (Northeast Atlantic)
}

\author{
Pablo Estevez ${ }^{1}{ }^{(}$, Manoëlla Sibat ${ }^{2}{ }^{\circledR}$, José Manuel Leão-Martins ${ }^{1}{ }^{\circledR}$, Angels Tudó ${ }^{3}{ }^{(0}$, \\ Maria Rambla-Alegre ${ }^{3}$, Katerina Aligizaki ${ }^{4}$, Jorge Diogène ${ }^{3, *}{ }^{\infty}$, Ana Gago-Martinez ${ }^{1, *}$ and \\ Philipp Hess $2, *$ (1) \\ 1 Biomedical Research Center (CINBIO), Department of Analytical and Food Chemistry, Campus Universitario \\ de Vigo, University of Vigo, 36310 Vigo, Spain; paestevez@uvigo.es (P.E.); leao@uvigo.es (J.M.L.-M.) \\ 2 Laboratoire Phycotoxines, Ifremer, Rue de l'Île d'Yeu 44311 Nantes, France; manoella.sibat@ifremer.fr \\ 3 Marine and Continental Waters programme, Ctra. Poble Nou, km. 5.5, IRTA, Sant Carles de la Ràpita, \\ 43540 Tarragona, Spain; angels.tudo@irta.cat (A.T.); maria.rambla@irta.cat (M.R.-A.) \\ 4 Laboratory Unit on Harmful Marine Microalgae, Biology Department, Aristotle University of Thessaloniki, \\ 54124 Thessaloniki, Greece; aligiza@auth.gr \\ * Correspondence: jorge.diogene@irta.cat (J.D.); anagago@uvigo.es (A.G.-M.); philipp.hess@ifremer.fr (P.H.); \\ Tel.: +34-97-774-3381 (J.D.); +34-64-734-3417 (A.G.-M.); +332-4037-4257 (P.H.)
}

Received: 25 March 2020; Accepted: 4 May 2020; Published: 7 May 2020

\begin{abstract}
Over the last decade, knowledge has significantly increased on the taxonomic identity and distribution of dinoflagellates of the genera Gambierdiscus and Fukuyoa. Additionally, a number of hitherto unknown bioactive metabolites have been described, while the role of these compounds in ciguatera poisoning (CP) remains to be clarified. Ciguatoxins and maitotoxins are very toxic compounds produced by these dinoflagellates and have been described since the 1980s. Ciguatoxins are generally described as the main contributors to this food intoxication. Recent reports of $\mathrm{CP}$ in temperate waters of the Canary Islands (Spain) and the Madeira archipelago (Portugal) triggered the need for isolation and cultivation of dinoflagellates from these areas, and their taxonomic and toxicological characterization. Maitotoxins, and specifically maitotoxin- 4 , has been described as one of the most toxic compounds produced by these dinoflagellates (e.g., G. excentricus) in the Canary Islands. Thus, characterization of toxin profiles of Gambierdiscus species from adjacent regions appears critical. The combination of liquid chromatography coupled to either low- or high-resolution mass spectrometry allowed for characterization of several strains of Gambierdiscus and Fukuyoa from the Mediterranean Sea and the Canary Islands. Maitotoxin-3, two analogues tentatively identified as gambieric acid $\mathrm{C}$ and $\mathrm{D}$, a putative gambierone analogue and a putative gambieroxide were detected in all G. australes strains from Menorca and Mallorca (Balearic Islands, Spain) while only maitotoxin-3 was present in an F. paulensis strain of the same region. An unidentified Gambierdiscus species (Gambierdiscus sp.2) from Crete (Greece) showed a different toxin profile, detecting both maitotoxin-3 and gambierone, while the availability of a G. excentricus strain from the Canary Islands (Spain) confirmed the presence of maitotoxin- 4 in this species. Overall, this study shows that toxin profiles not only appear to be species-specific but probably also specific to larger geographic regions.
\end{abstract}


Keywords: maitotoxins; ciguatoxins; Gambierdiscus; Fukuyoa; LC-MS/MS; HRMS; QToF; ciguatera poisoning

Key Contribution: Metabolites were identified in several Gambierdiscus strains from the Balearic Islands, Greece and the Canaries. High-resolution mass spectrometry confirmed the presence of 44-methyl gambierone (MTX3) and did not detect maitotoxin-1 (MTX1), desulfo-MTX1 and didehydro-desulfo-MTX1 above the detection limit in Mediterranean strains of G. australes.

\section{Introduction}

Ciguatera Poisoning $(\mathrm{CP})$ is described as a food intoxication endemic in tropical and subtropical areas of the world. The poisoning is caused by the consumption of fish or shellfish that accumulate toxic compounds produced by benthic dinoflagellates of the genus Gambierdiscus and Fukuyoa [1]. The two main toxin groups produced by these dinoflagellates are ciguatoxins (CTXs) and maitotoxins (MTXs) [2].

CTXs are considered the main toxins responsible for $\mathrm{CP}$ as their lipophilic character allows for intestinal absorption and accumulation. They are cyclic polyether compounds of around 1100 Da being classified as Pacific (P-CTXs), Caribbean (C-CTXs) and Indian (I-CTXs) ciguatoxins. Different CTX analogues from these groups have been detected in fish tissue associated to a $\mathrm{CP}$ case, while only a few P-CTXs were detected in Gambierdiscus extracts from the Pacific Ocean [3-7].

MTXs are water soluble cyclic polyethers containing one or two sulfate ester groups; these groups are responsible for the intermediate polarity of MTXs, and their low intestinal absorption casts doubts as to their involvement in CP [8]. Six MTX analogues have currently been identified: maitotoxin-1 (MTX1), maitotoxin-2 (MTX2), maitotoxin-3 (MTX3), maitotoxin-4 (MTX4), desulfo-MTX1 and didehydrodemethyl-desulfo-MTX1, all of which were isolated from different strains of Gambierdiscus [9-12].

MTX1 is the most toxic marine compound and the largest natural non-biopolymer toxin consisting on a ladder-shaped cyclic polyether compound containing two sulfate groups [9]. MTX2 was isolated from an Australian Gambierdiscus strain from Queensland [10]. Its structure has not yet been elucidated and it showed a lower potency than MTX1 by intraperitoneal injection in mice. MTX3 (44-methylgambierone) was first characterized by [10], but it was not until recently that its structure had been elucidated by its isolation from G. belizeanus and G. australes, being identified as a gambierone homologue [13-15]. MTX3, which is about one third the molecular weight of MTX1, showed a biological activity similar to CTX3C but with much lower potency, indicating that despite being grouped in the MTX group, this compound exhibits CTX-like activity rather than MTX-like activity [13]. MTX4 was recently isolated from G. excentricus extracts from the Canary Islands (Spain) [11]. Its structure is not yet elucidated but it has ion clusters and molecular mass in a similar range as MTX1, as well as sulfate esters; it was reported to exhibit a similar toxic effect of MTX1 in neuroblastoma cells detecting a high cytotoxicity and $\mathrm{Ca}^{2+}$ influx [11]. Other large but mono-sulfated MTXs were recently elucidated by their isolation from Gambierdiscus spp. from the Caribbean Sea, i.e., desulfo-MTX1 from G. belizeanus and didehydro-demethyl-desulfo-MTX1 from G. ribotype-2, showing the wide variety of MTXs that seem to be produced by these dinoflagellates [12] (Table 1). Furthermore, Gambierdiscus and Fukuyoa have shown to produce non-structurally related cyclic polyether compounds such as gambierol, gambieric acids, gambieroxide and gambierone [15-18]. 
Table 1. List of the maitotoxins isolated from dinoflagellates of the genus Gambierdiscus and Fukuyoa.

\begin{tabular}{ccccc}
\hline MTX Congener & Chemical Formula & Monoisotopic Mass (Da) & Reference \\
\hline MTX1 & $\mathrm{C}_{164} \mathrm{H}_{258} \mathrm{O}_{68} \mathrm{~S}_{2}$ & 3379.6171 for the free acid form & {$[9]$} \\
MTX2 & Unknown & 3298 for the mono-sodium salt & {$[10]$} \\
MTX3 & $\mathrm{C}_{52} \mathrm{H}_{78} \mathrm{O}_{19} \mathrm{~S}$ & 1038.4858 for the free acid form & {$[13,14]$} \\
MTX4 & Unknown & 3292.486 for the free acid form & {$[11]$} & {$[12]$} \\
desulfo-MTX1 & $\mathrm{C}_{164} \mathrm{H}_{258} \mathrm{O}_{65} \mathrm{~S}$ & 3299.6603 for the free acid form & {$[12]$} \\
\hline
\end{tabular}

Most of these compounds can be classified depending on their mechanism of action into two groups: (i) MTX-like compounds, associated with a massive $\mathrm{Ca}^{2+}$ influx causing a rapid cell death, including MTX1, MTX2 and MTX4; and (ii) CTX-like compounds, which create a disequilibrium in the voltage-gated sodium channels (VGSCs), including all CTXs, and with much lower potency, MTX3 and gambierone [13].

A wide variety of Gambierdiscus species are present in regions considered endemic for $\mathrm{CP}$ (the Pacific Ocean or the Caribbean Sea) [19]. These dinoflagellates have also been detected in CP-emerging regions such as the Canary Islands (Spain) and Madeira archipelago (Portugal), as well as in the Mediterranean Sea, from which no CP cases have been reported until now [20]. Gambierdiscus excentricus was the first Gambierdiscus species detected in the Canary Islands [21], but its detection led to further research that concluded with the detection of a large number of Gambierdiscus species (G. australes, G. caribaeus, G. carolinianus, G. excentricus, G. silvae and Gambierdiscus ribotype3) suggesting that the Canary Islands would be a "hot spot" for these dinoflagellates [22]. On the other hand, the only available data from the Selvagem Islands (Madeira, Portugal) is the detection of numerous strains of G. australes, which test positive in the Neuro2a cell-based toxicity assay (N2a), suggesting they contain CTX-and MTX-like compounds [23]. In the Mediterranean Sea, the presence of Gambierdiscus was first reported in 2003 (Gambierdiscus sp.) in Crete (Greece), while to our knowledge only one study in 2016 attempted to characterize a strain of F. paulensis from Formentera (Balearic Islands, Spain) by LC-MS, however, the trace levels of toxic compounds present did not allow for conclusive results about the compounds produced $[24,25]$.

As part of the ongoing EuroCigua project [26], G. australes and F. paulensis were isolated from Menorca and Mallorca (Balearic Islands, Spain), Gambierdiscus sp.2 from Crete (Greece), as well as G. excentricus from La Gomera (Canary Islands, Spain), showing CTX and MTX-activity. The aim of the present study was to describe the diversity of toxins produced by a selection of these strains of Gambierdiscus and Fukuyoa species using liquid chromatography coupled to low- and high-resolution mass spectrometry (LC-MS/MS and LC-HRMS). While LC-MS/MS was used for a rapid screening of the toxic compounds potentially present, allowing for the estimation of their concentrations, the purpose of LC-HRMS was the confirmation and structural characterization of the toxic compounds previously identified by LC-MS/MS.

\section{Results}

\subsection{LC-MS/MS Analysis}

In an attempt to separate MTXs and gambierones from CTXs, liquid/liquid partitioning of the crude extracts was carried out between $\mathrm{MeOH}: \mathrm{H}_{2} \mathrm{O}$ (3:2) and dichloromethane. The methanol-soluble fraction (MSF) and the dichloromethane-soluble fraction (DSF) of each crude extract of dinoflagellate cell pellets were analyzed by LC-MS/MS monitoring MTXs, as well as gambierone (Table 2). A Multiple Reaction Monitoring (MRM) method in negative ionization mode screened for six MTXs (MTX1, MTX2, MTX3, MTX4, desulfo-MTX1 and didehydro-demethyl-desulfo-MTX1), as well as gambierone. The ESI ${ }^{-}$MRM method was based on monitoring a qualitative transition from the (pseudo-)molecular ion to the hydrogenated sulfate anion $\mathrm{m} / \mathrm{z} 96.9\left[\mathrm{HOSO}_{3}\right]^{-}$at high collision energy, which is typical 
of these compounds, and for quantitation based on monitoring the pseudo-molecular ion itself $[\mathrm{M}-2 \mathrm{H}]^{2-} /[\mathrm{M}-2 \mathrm{H}]^{2-}$ for MTX1, MTX4, desulfo-MTX1 and didehydro-demethyl-desulfo-MTX1. This was due to the single-charged ion of these compounds being outside the mass range of the mass spectrometer (50-2800 Da), whereas $[\mathrm{M}-\mathrm{H}]^{-} /[\mathrm{M}-\mathrm{H}]^{-}$was selected for MTX3 and gambierone. Due to the absence of MTX2 MS/MS fragmentation data, the double-charged $[\mathrm{M}-2 \mathrm{H}]^{2-} /\left[\mathrm{HOSO}_{3}\right]^{-}$and triple-charged $[\mathrm{M}-3 \mathrm{H}]^{3-} /\left[\mathrm{HOSO}_{3}\right]^{-}$molecular anions to the sulfate anion $\mathrm{m} / \mathrm{z} 96.9\left[\mathrm{HOSO}_{3}\right]^{-}$were selected as MRM transitions for this compound, assuming similar MS/MS fragmentation behavior of MTX1 and MTX2 [27].

The identification of MTX1, MTX3, gambierone and MTX4 was carried out by comparing retention times as well as ion ratios with the reference materials available (Table S8). On the other hand, the lack of structural information and reference material of MTX2 limited its identification. Therefore, the absence of this compound was reported as not detected above the limit of detection of any ion transition monitored. The lack of reference material of desulfo-MTX1 and didehydro-demethyl-desulfo-MTX1 also limited its identification, with the approach followed being the same as that described for MTX2. However, the accurate mass of these compounds was available, only hampering its identification in LC-HRMS by the uncertainty of the limit of detection of our method for these compounds.

44-methyl-gambierone (MTX3) was identified in all samples of G. australes from Menorca and Mallorca (Balearic Islands, Spain), detecting both quantitative m/z $1037.6[\mathrm{M}-\mathrm{H}]^{-} / \mathrm{m} / z$ 1037.6 [M-H] and qualitative $m / z$ 1037.6 $[\mathrm{M}-\mathrm{H}]^{-} / \mathrm{m} / z$ 96.9 $\left[\mathrm{HOSO}_{3}\right]^{-} \mathrm{MRM}$ ion transitions in negative ionization mode. MTX3 concentrations in G. australes strains ranged from 344 to $1661 \mathrm{pg}$ MTX1 equivalent/cell (eq./cell) taking into account the total amount detected in the sum of MSF + DSF. Gambierdiscus sp.2 from Crete (Greece) contained significantly less MTX3 (4.3 pg MTX1 eq./cell). The recovery of MTX3 in the MSF ranged between $66.7 \%$ and $84.1 \%$ for G. australes for the Balearic and Crete strains (Table 2). MTX3 was also present in one F. paulensis from Menorca (Balearic Islands, Spain) at a concentration of $10.5 \mathrm{pg}$ MTX1 eq./cell. In this case, however, the recovery of MTX3 in the MSF was only $17.7 \%$ (Table 2). This difference compared to the recovery observed in the MTX3 detected in G. australes must be explored; at this stage, we can only presume a matrix effect during the partitioning step. Gambierone was only identified in the one Gambierdiscus strain from Crete, albeit at a significant concentration of 776 pg MTX1 eq./cell for the sum of MSF + DSF. The recovery of gambierone in the MSF was $92.2 \%$ (Table 2).

A putative gambierone analogue, with an earlier retention time than gambierone on the $\mathrm{C}_{18}$ column, was detected in all G. australes from Menorca and Mallorca (Balearic Islands, Spain) at concentrations ranging from 148.6 to $523.4 \mathrm{pg}$ MTX1 eq./cell and an average recovery of the putative gambierone analogue in the MSF of $99.7 \%$ (Table 2). Negative ionization mode detected both quantitative $\mathrm{m} / \mathrm{z}$ $1023.5[\mathrm{M}-\mathrm{H}]^{-} / \mathrm{m} / \mathrm{z} 1023.5$ [M-H] $^{-}$and qualitative ion transitions $\mathrm{m} / \mathrm{z} 1023.5[\mathrm{M}-\mathrm{H}]^{-} / \mathrm{m} / \mathrm{z} 96.9$ [HOSO $\left._{3}\right]^{-}$ with the same ion ratios as gambierone. This compound was not present in the other three strains of Gambierdiscus.

Further confirmation of MTX3, gambierone and the putative gambierone analogue was carried out in positive ionization mode and not only in MRM, but also in full scan and enhanced product ion modes, confirming the presence of MTX3 and gambierone due to the detection of their common fragment $m / z$ 803 as well as their specific fragments $m / z 233$ and $m / z 219$, respectively. This was already reported by Boente-Juncal et al. [13], and a common fragment with $m / z 109$ was assigned to the fragmentation of the side chain in the last ring (Figures S1 and S2). The putative gambierone analogue did not show any common or specific gambierone fragments but showed a fragmentation pattern similar to these compounds, including water losses and sulfate loss followed by water losses (Figures S1 and S2).

MTX4 was confirmed in a strain of G. excentricus from La Gomera (Canary Islands, Spain). Retention time as well as MRM ion ratios transitions $m / z 1646.2[\mathrm{M}-2 \mathrm{H}]^{2-} / \mathrm{m} / z 1646.2[\mathrm{M}-2 \mathrm{H}]^{2-}$ and $m / z 1646.2[\mathrm{M}-2 \mathrm{H}]^{2-} / \mathrm{m} / z 96.9\left[\mathrm{HOSO}_{3}\right]^{-}$were consistent with those obtained in the MTX4 reference material. The recovery of MTX4 from the DSF to the MSF was 99.3\% (See Table 2). 
Table 2. Results obtained after the liquid chromatography mass spectrometry (LC-MS/MS) analysis of the dinoflagellate extracts using a triple-stage quadrupole instrument. Results are expressed in pg MTX1 eq./cell: equivalent/cell; MSF: Methanol Soluble Fraction; DSF: Dichloromethane Soluble Fraction; $\Sigma$ : sum, n.d.: not detected.

\begin{tabular}{|c|c|c|c|c|c|c|c|c|c|c|c|c|c|c|c|c|c|c|}
\hline \multirow{3}{*}{ Species } & \multirow{3}{*}{$\begin{array}{l}\text { Strain } \\
\text { Code }\end{array}$} & \multirow{3}{*}{ Location } & \multirow[b]{3}{*}{ MTX1 } & \multirow[b]{3}{*}{ MTX2 } & \multirow{2}{*}{\multicolumn{3}{|c|}{ MTX3 }} & \multicolumn{8}{|c|}{$\begin{array}{l}\text { pg MTX1 eq./Cell } \\
\text { (\% of TOTAL) }\end{array}$} & \multirow{2}{*}{\multicolumn{3}{|c|}{ P-Gambierone Analogue }} \\
\hline & & & & & & & & \multicolumn{3}{|c|}{ MTX4 } & \multirow[b]{2}{*}{$\begin{array}{l}\text { desulfo- } \\
\text { MTX1 }\end{array}$} & \multirow{2}{*}{$\begin{array}{c}\text { didehydro- } \\
\text { demethyl- } \\
\text { desulfo-MTX1 }\end{array}$} & \multicolumn{3}{|c|}{ Gambierone } & & & \\
\hline & & & & & $\begin{array}{l}\text { MSF } \\
(\%)\end{array}$ & $\begin{array}{l}\text { DSF } \\
(\%)\end{array}$ & $\Sigma$ & $\begin{array}{l}\text { MSF } \\
(\%)\end{array}$ & $\begin{array}{l}\text { DSF } \\
(\%)\end{array}$ & $\Sigma$ & & & $\begin{array}{l}\text { MSF } \\
(\%)\end{array}$ & $\begin{array}{l}\text { DSF } \\
(\%)\end{array}$ & $\Sigma$ & $\begin{array}{l}\text { MSF } \\
(\%)\end{array}$ & $\begin{array}{l}\text { DSF } \\
(\%)\end{array}$ & $\Sigma$ \\
\hline G. australes & $\begin{array}{l}\text { IRTA-SMM- } \\
17-189\end{array}$ & $\begin{array}{l}\text { Torret, Menorca, } \\
\text { Balearic Islands, Spain }\end{array}$ & n.d. & n.d. & $\begin{array}{c}241 \\
(70.2) \\
\end{array}$ & $\begin{array}{c}102 \\
(29.8) \\
\end{array}$ & 344.0 & & n.d. & & n.d. & n.d. & & n.d. & & $\begin{array}{c}148 \\
(99.7)\end{array}$ & $\begin{array}{c}0.4 \\
(0.3)\end{array}$ & 149 \\
\hline G. australes & $\begin{array}{l}\text { IRTA-SMM- } \\
17-162\end{array}$ & $\begin{array}{l}\text { St. Adeodat, Menorca, } \\
\text { Balearic Islands, Spain }\end{array}$ & n.d. & n.d. & $\begin{array}{c}575 \\
(79.9) \\
\end{array}$ & $\begin{array}{c}150 \\
(20.1)\end{array}$ & 720 & & n.d. & & n.d. & n.d. & & n.d. & & $\begin{array}{c}275 \\
(99.6)\end{array}$ & $\begin{array}{c}1.0 \\
(0.4)\end{array}$ & 276 \\
\hline G. australes & $\begin{array}{l}\text { IRTA-SMM- } \\
17-164\end{array}$ & $\begin{array}{l}\text { St. Adeodat, Menorca, } \\
\text { Balearic Islands, Spain }\end{array}$ & n.d. & n.d. & $\begin{array}{l}1108 \\
(66.7) \\
\end{array}$ & $\begin{array}{c}553 \\
(33.3) \\
\end{array}$ & 1661 & & n.d. & & n.d. & n.d. & & n.d. & & $\begin{array}{c}522 \\
(99.8) \\
\end{array}$ & $\begin{array}{c}1.2 \\
(0.2)\end{array}$ & 523 \\
\hline G. australes & $\begin{array}{l}\text { IRTA-SMM- } \\
17-271\end{array}$ & $\begin{array}{l}\text { Macarella, Menorca, } \\
\text { Balearic Islands, Spain }\end{array}$ & n.d. & n.d. & $\begin{array}{l}1107 \\
(83.7) \\
\end{array}$ & $\begin{array}{c}215 \\
(16.3) \\
\end{array}$ & 1322 & & n.d. & & n.d. & n.d. & & n.d. & & $\begin{array}{c}408 \\
(99.9) \\
\end{array}$ & $\begin{array}{c}0.4 \\
(0.1)\end{array}$ & 409 \\
\hline F. paulensis & $\begin{array}{l}\text { IRTA-SMM- } \\
17-209\end{array}$ & $\begin{array}{l}\text { Sacaleta, Menorca, } \\
\text { Balearic Islands, Spain }\end{array}$ & n.d. & n.d. & $\begin{array}{c}1.8 \\
(17.7) \\
\end{array}$ & $\begin{array}{c}8.6 \\
(82.3) \\
\end{array}$ & 10.5 & & n.d. & & n.d. & n.d. & & n.d. & & & n.d. & \\
\hline G. australes & $\begin{array}{l}\text { IRTA-SMM- } \\
\text { 17-253 }\end{array}$ & $\begin{array}{l}\text { Anguila, Mallorca, } \\
\text { Balearic Islands, Spain }\end{array}$ & n.d. & n.d. & $\begin{array}{c}781 \\
(72.3) \\
\end{array}$ & $\begin{array}{c}300 \\
(27.7) \\
\end{array}$ & 1081 & & n.d. & & n.d. & n.d. & & n.d. & & $\begin{array}{c}229 \\
(99.8) \\
\end{array}$ & $\begin{array}{c}0.5 \\
(0.2)\end{array}$ & 229 \\
\hline G. australes & $\begin{array}{l}\text { IRTA-SMM- } \\
\quad \text { 17-244 }\end{array}$ & $\begin{array}{l}\text { Camp de Mar, } \\
\text { Mallorca, Balearic } \\
\text { Islands, Spain }\end{array}$ & n.d. & n.d. & $\begin{array}{c}403 \\
(84.1)\end{array}$ & $\begin{array}{c}75.9 \\
(15.9)\end{array}$ & 479 & & n.d. & & n.d. & n.d. & & n.d. & & $\begin{array}{c}173 \\
(99.6)\end{array}$ & $\begin{array}{c}0.7 \\
(0.4)\end{array}$ & 174 \\
\hline $\begin{array}{l}\text { Gambierdiscus } \\
\text { sp.2 }\end{array}$ & $\begin{array}{l}\text { 0010G-CR- } \\
\text { CCAUTH }\end{array}$ & $\begin{array}{l}\text { Kolimpari, Crete, } \\
\text { Greece }\end{array}$ & n.d. & n.d. & $\begin{array}{c}3.0 \\
(70.1) \\
\end{array}$ & $\begin{array}{c}1.3 \\
(29.9) \\
\end{array}$ & 4.3 & & n.d. & & n.d. & n.d. & $\begin{array}{c}716 \\
(92.2) \\
\end{array}$ & $\begin{array}{l}60.3 \\
(7.8) \\
\end{array}$ & 775.9 & & n.d. & \\
\hline $\begin{array}{c}\text { G. } \\
\text { excentricus }\end{array}$ & $\begin{array}{l}\text { IRTA-SMM- } \\
\quad 17-407\end{array}$ & $\begin{array}{l}\text { Playa de vueltas, La } \\
\text { Gomera, Canary } \\
\text { Islands, Spain }\end{array}$ & n.d. & n.d. & & n.d. & & $\begin{array}{l}36.8 \\
(99.3)\end{array}$ & $\begin{array}{c}0.3 \\
(0.7)\end{array}$ & 37.1 & n.d. & n.d. & & n.d. & & & n.d. & \\
\hline
\end{tabular}


MTX1, MTX2, desulfo-MTX1 and didehydro-demethyl-desulfo-MTX1 were not detected in any Gambierdiscus or Fukuyoa samples from the Mediterranean Sea and the G. excentricus from Canary Islands (Spain), neither in the MSF nor in the DSF.

\subsection{LC-HRMS/MS Analysis}

The presence of the compounds previously identified and quantified by LC-MS/MS was confirmed by LC-HRMS. Mass spectral detection was performed in full scan and targeted MS/MS mode in negative $\left(\mathrm{ESI}^{-}\right)$and positive $\left(\mathrm{ESI}^{+}\right)$ionization mode. Both DSF and MSF of dinoflagellate extracts were analyzed in $\mathrm{ESI}^{-}$and $\mathrm{ESI}^{+}$full scan mode, and screening with an in-house database allowed for identification of several compounds based on their characteristics reported in the literature.

MTX3 was confirmed in all G. australes in both $\mathrm{ESI}^{-}$and $\mathrm{ESI}^{+}$full scan mode at $7.6 \mathrm{~min}$. Negative ionization mode showed the detection of a single ion corresponding to the deprotonated molecule $[\mathrm{M}-\mathrm{H}]^{-}$with $\Delta \mathrm{ppm}<1 \mathrm{ppm}$ in all samples of this species (Figure 1A1, Table S1). At the same retention time, positive ionization mode showed a prominent ion corresponding to the molecular ion $[\mathrm{M}+\mathrm{H}]^{+}$ and also pseudo-molecular ions $\left[\mathrm{M}+\mathrm{H}_{-} \mathrm{H}_{2} \mathrm{O}\right]^{+},\left[\mathrm{M}+\mathrm{NH}_{4}\right]^{+},[\mathrm{M}+\mathrm{Na}]^{+}$with $\Delta \mathrm{ppm}<3.7 \mathrm{ppm}$ in all ions of these samples (Figure 1A) (See Table S1).
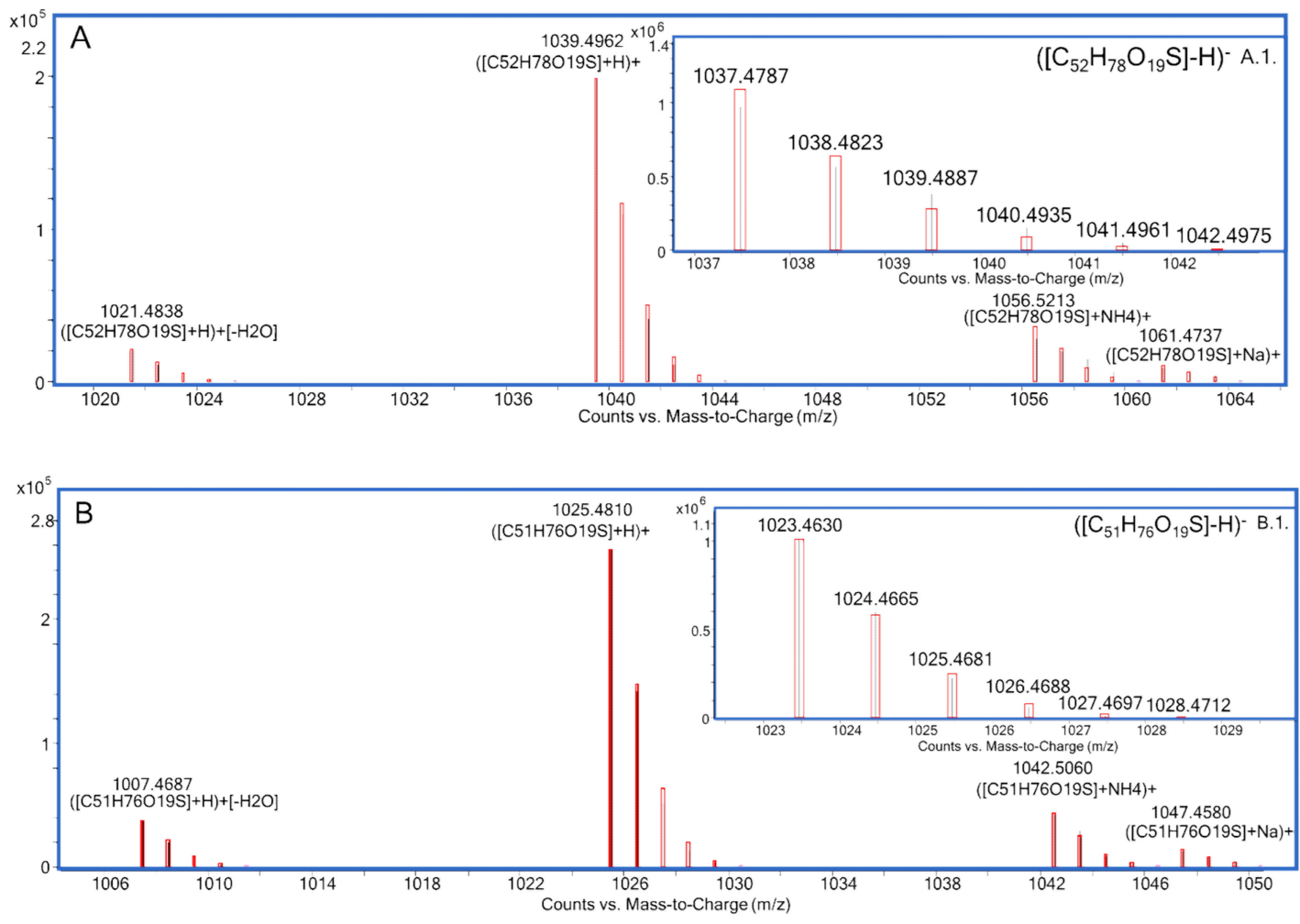

Figure 1. LC-HRMS analysis in MS full scan mode of: MTX3 detected in G. australes, (A) $\mathrm{ESI}^{+}$mode, (A1) $\mathrm{ESI}^{-}$mode; gambierone detected in Gambierdiscus sp.2, (B) $\mathrm{ESI}^{+}$mode, (B1) $\mathrm{ESI}^{-}$mode.

The molecular ion [M-H] $]^{-}$of MTX3 was also detected in F. paulensis and Gambierdiscus sp.2 in $\mathrm{ESI}^{-}$ionization mode at $7.6 \mathrm{~min}$ with a $\Delta \mathrm{ppm}<1.9 \mathrm{ppm}$, whereas the lower sensitivity of the $\mathrm{ESI}^{+}$ ionization mode for this compound only allowed the detection of the molecular ion $[\mathrm{M}+\mathrm{H}]^{+}$with $\Delta \mathrm{ppm}<2.2 \mathrm{ppm}$ and traces of the first water loss $\left[\mathrm{M}+\mathrm{H}_{-} \mathrm{H}_{2} \mathrm{O}\right]^{+}(\Delta \mathrm{ppm}<8 \mathrm{ppm})$ (See Table S1).

Gambierone was identified at $7.4 \mathrm{~min}$ in the Gambierdiscus sp.2 from Crete (Greece) showing a similar ion pattern as the one detected for MTX3 in both ESI ${ }^{-}$and ESI ${ }^{+}$full scan mode. Negative ionization mode showed the detection of a single ion matching the deprotonated molecule $[\mathrm{M}-\mathrm{H}]^{-} \mathrm{m} / \mathrm{z}$ $1023.4630(\Delta \mathrm{ppm}=+0.1 \mathrm{ppm})$ (Figure 1B1, Table S2). Positive ionization mode showed, at the same retention time, a prominent ion corresponding to the molecular ion $[\mathrm{M}+\mathrm{H}]^{+} \mathrm{m} / z 1025.4810(\Delta \mathrm{ppm}=$ 
$+3.5 \mathrm{ppm})$ and also the pseudo-molecular ions $\left[\mathrm{M}+\mathrm{H}-\mathrm{H}_{2} \mathrm{O}\right]^{+} \mathrm{m} / \mathrm{z} 1007.4687(\Delta \mathrm{ppm}=+1.8),\left[\mathrm{M}+\mathrm{NH}_{4}\right]^{+}$ $\mathrm{m} / \mathrm{z} 1042.5060(\Delta \mathrm{ppm}=+1.9)$ and $[\mathrm{M}+\mathrm{Na}]^{+} \mathrm{m} / \mathrm{z} 1047.4580(\Delta \mathrm{ppm}=-1.3)$ (Figure 1B, Table S2).

MTX3 and gambierone were further confirmed in targeted MS/MS in both $\mathrm{ESI}^{-}$and $\mathrm{ESI}^{+}$mode. ESI $^{-}$-targeted MS/MS selected the deprotonated molecule $[\mathrm{M}-\mathrm{H}]^{-}$applying $30 \mathrm{eV}, 50 \mathrm{eV}$ and $70 \mathrm{eV}$, detecting the hydrogen-sulfate fragment $\left[\mathrm{HOSO}_{3}\right]^{-}$in both compounds (Figures $2 \mathrm{~A}$ and $2 \mathrm{~B}$ ). An ion representing a water loss $\left[\mathrm{M}-\mathrm{H}-\mathrm{H}_{2} \mathrm{O}\right]^{-}$was also detected in low abundance, as well as the fragments specific for MTX3, $m / z 977.4535(\Delta \mathrm{ppm}=-4.0 \mathrm{ppm})$ and $m / z 959.4428(\Delta \mathrm{ppm}=-4.2 \mathrm{ppm})$, and those specific for gambierone, $\mathrm{m} / \mathrm{z} 963.4392(\Delta \mathrm{ppm}=-2.6 \mathrm{ppm})$ and $\mathrm{m} / \mathrm{z} 945.4302(\Delta \mathrm{ppm}=-1.0 \mathrm{ppm})$. Fragmentation pathways are also proposed on the basis of the observed fragments, including the two common fragments with theoretical $\mathrm{m} / \mathrm{z} 899.3741$ and $\mathrm{m} / \mathrm{z} 839.3529$, as well as water losses common to both MTX3 and gambierone (Figures 2A1 and 2B1) (Table 3).

Table 3. Accurate masses (measured and theoretical) of informative ions of MTX3 and gambierone in $\mathrm{ESI}^{-}$mode and $\mathrm{ESI}^{+}$mode.

\begin{tabular}{|c|c|c|c|c|c|c|c|c|}
\hline \multirow{3}{*}{ Ion } & \multicolumn{4}{|c|}{ MTX3 } & \multicolumn{4}{|c|}{ Gambierone } \\
\hline & \multirow{2}{*}{$\begin{array}{l}\text { Molecular } \\
\text { Formula }\end{array}$} & \multicolumn{2}{|c|}{$\mathrm{m} / \mathrm{z}$} & \multirow{2}{*}{$\Delta \mathrm{ppm}$} & \multirow{2}{*}{$\begin{array}{l}\text { Molecular } \\
\text { Formula }\end{array}$} & \multicolumn{2}{|c|}{$\mathrm{m} / \mathrm{z}$} & \multirow{2}{*}{$\Delta \mathrm{ppm}$} \\
\hline & & Measured & Theoretical & & & Measured & Theoretical & \\
\hline \multicolumn{9}{|c|}{$\mathrm{ESI}^{-}$} \\
\hline$[\mathrm{M}-\mathrm{H}]^{-}$ & $\mathrm{C}_{52} \mathrm{H}_{77} \mathrm{O}_{19} \mathrm{~S}^{-}$ & 1037.4774 & 1037.4785 & -1.1 & $\mathrm{C}_{51} \mathrm{H}_{75} \mathrm{O}_{19} \mathrm{~S}^{-}$ & 1023.4612 & 1023.4629 & -1.6 \\
\hline \multirow[t]{2}{*}[\mathrm{M}-\mathrm{H}-\mathrm{H}_{2}\mathrm{O}]{$^{-}$} & $\mathrm{C}_{52} \mathrm{H}_{75} \mathrm{O}_{18} \mathrm{~S}^{-}$ & 1019.4625 & 1019.4680 & -5.3 & $\mathrm{C}_{51} \mathrm{H}_{73} \mathrm{O}_{18} \mathrm{~S}^{-}$ & 1005.4463 & 1005.4523 & -6.0 \\
\hline & $\mathrm{C}_{50} \mathrm{H}_{73} \mathrm{O}_{17} \mathrm{~S}^{-}$ & 977.4535 & 977.4574 & -4.0 & $\mathrm{C}_{49} \mathrm{H}_{71} \mathrm{O}_{17} \mathrm{~S}^{-}$ & 963.4392 & 963.4417 & -2.6 \\
\hline \multirow[t]{2}{*}{$\mathrm{H}_{2} \mathrm{O}$} & $\mathrm{C}_{50} \mathrm{H}_{71} \mathrm{O}_{16} \mathrm{~S}^{-}$ & 959.4428 & 959.4468 & -4.2 & $\mathrm{C}_{49} \mathrm{H}_{69} \mathrm{O}_{16} \mathrm{~S}^{-}$ & 945.4302 & 945.4312 & -1.0 \\
\hline & $\mathrm{C}_{43} \mathrm{H}_{63} \mathrm{O}_{18} \mathrm{~S}^{-}$ & 899.3707 & 899.3741 & -3.7 & $\mathrm{C}_{43} \mathrm{H}_{63} \mathrm{O}_{18} \mathrm{~S}^{-}$ & 899.3707 & 899.3741 & -3.7 \\
\hline \multirow[t]{2}{*}{$-\mathrm{H}_{2} \mathrm{O}$} & $\mathrm{C}_{43} \mathrm{H}_{61} \mathrm{O}_{17} \mathrm{~S}^{-}$ & 881.3613 & 881.3635 & -2.5 & $\mathrm{C}_{43} \mathrm{H}_{61} \mathrm{O}_{17} \mathrm{~S}^{-}$ & 881.3618 & 881.3635 & -1.9 \\
\hline & $\mathrm{C}_{41} \mathrm{H}_{59} \mathrm{O}_{16} \mathrm{~S}^{-}$ & 839.3501 & 839.3529 & -3.4 & $\mathrm{C}_{41} \mathrm{H}_{59} \mathrm{O}_{16} \mathrm{~S}^{-}$ & 839.3517 & 839.3529 & -1.5 \\
\hline$-\mathrm{H}_{2} \mathrm{O}$ & $\mathrm{C}_{41} \mathrm{H}_{57} \mathrm{O}_{15} \mathrm{~S}^{-}$ & 821.3362 & 821.3424 & -7.5 & $\mathrm{C}_{41} \mathrm{H}_{57} \mathrm{O}_{15} \mathrm{~S}^{-}$ & 821.3306 & 821.3424 & -14.3 \\
\hline$\left[\mathrm{HOSO}_{3}\right]^{-}$ & $\mathrm{HOSO}_{3}^{-}$ & 96.9611 & 96.9601 & 10.3 & $\mathrm{HOSO}_{3}^{-}$ & 96.9615 & 96.9601 & 14.4 \\
\hline \multicolumn{9}{|c|}{$\mathrm{ESI}^{+}$} \\
\hline$[\mathrm{M}+\mathrm{H}]^{+}$ & $\mathrm{C}_{52} \mathrm{H}_{79} \mathrm{O}_{19} \mathrm{~S}^{+}$ & 1039.4911 & 1039.4931 & -1.9 & $\mathrm{C}_{51} \mathrm{H}_{77} \mathrm{O}_{19} \mathrm{~S}^{+}$ & 1025.4749 & 1025.4774 & -2.4 \\
\hline$\left[\mathrm{M}+\mathrm{H}-\mathrm{H}_{2} \mathrm{O}\right]^{+}$ & $\mathrm{C}_{52} \mathrm{H}_{77} \mathrm{O}_{18} \mathrm{~S}^{+}$ & 1021.4795 & 1021.4825 & -2.9 & $\mathrm{C}_{51} \mathrm{H}_{75} \mathrm{O}_{18} \mathrm{~S}^{+}$ & 1007.4636 & 1007.4668 & -3.2 \\
\hline$\left[\mathrm{M}+\mathrm{H}-2 \mathrm{H}_{2} \mathrm{O}\right]^{+}$ & $\mathrm{C}_{52} \mathrm{H}_{75} \mathrm{O}_{17} \mathrm{~S}^{+}$ & 1003.4692 & 1003.4720 & -2.8 & $\mathrm{C}_{51} \mathrm{H}_{73} \mathrm{O}_{17} \mathrm{~S}^{+}$ & 989.4528 & 989.4563 & -3.5 \\
\hline$\left[\mathrm{M}-\mathrm{SO}_{3}+\mathrm{H}\right]^{+}$ & $\mathrm{C}_{52} \mathrm{H}_{79} \mathrm{O}_{16}{ }^{+}$ & 959.5333 & 959.5363 & -3.1 & $\mathrm{C}_{51} \mathrm{H}_{77} \mathrm{O}_{16}{ }^{+}$ & 945.5171 & 945.5206 & -3.7 \\
\hline$\left[\mathrm{M}-\mathrm{SO}_{3}-\mathrm{H}_{2} \mathrm{O}+\mathrm{H}\right]^{+}$ & $\mathrm{C}_{52} \mathrm{H}_{77} \mathrm{O}_{15}^{+}$ & 941.5232 & 941.5257 & -2.7 & $\mathrm{C}_{51} \mathrm{H}_{75} \mathrm{O}_{15}{ }^{+}$ & 927.5070 & 927.5100 & -3.2 \\
\hline$\left[\mathrm{M}-\mathrm{SO}_{3}-2 \mathrm{H}_{2} \mathrm{O}+\mathrm{H}\right]^{+}$ & $\mathrm{C}_{52} \mathrm{H}_{75} \mathrm{O}_{14}{ }^{+}$ & 923.5125 & 923.5152 & -2.9 & $\mathrm{C}_{51} \mathrm{H}_{73} \mathrm{O}_{14}{ }^{+}$ & 909.4968 & 909.4995 & -3.0 \\
\hline$\left[\mathrm{M}-\mathrm{SO}_{3}-3 \mathrm{H}_{2} \mathrm{O}+\mathrm{H}\right]^{+}$ & $\mathrm{C}_{52} \mathrm{H}_{73} \mathrm{O}_{13}{ }^{+}$ & 905.5022 & 905.5046 & -2.7 & $\mathrm{C}_{51} \mathrm{H}_{71} \mathrm{O}_{13}{ }^{+}$ & 891.4849 & 891.4889 & -4.5 \\
\hline$\left[\mathrm{M}-\mathrm{SO}_{3}-4 \mathrm{H}_{2} \mathrm{O}+\mathrm{H}\right]^{+}$ & $\mathrm{C}_{52} \mathrm{H}_{71} \mathrm{O}_{12}{ }^{+}$ & 887.4911 & 887.4940 & -3.3 & $\mathrm{C}_{51} \mathrm{H}_{69} \mathrm{O}_{12}{ }^{+}$ & 873.4743 & 873.4783 & -4.6 \\
\hline \multirow[t]{2}{*}[\mathrm{M}-\mathrm{SO}_{3}-5\mathrm{H}_{2}\mathrm{O}+\mathrm{H}]{$^{+}$} & $\mathrm{C}_{52} \mathrm{H}_{69} \mathrm{O}_{11}{ }^{+}$ & 869.4812 & 869.4835 & -2.6 & $\mathrm{C}_{51} \mathrm{H}_{67} \mathrm{O}_{11}{ }^{+}$ & 855.4656 & 855.4678 & -2.6 \\
\hline & $\mathrm{C}_{43} \mathrm{H}_{65} \mathrm{O}_{18} \mathrm{~S}^{+}$ & 901.3854 & 901.3886 & -3.6 & $\mathrm{C}_{43} \mathrm{H}_{65} \mathrm{O}_{18} \mathrm{~S}^{+}$ & 901.3884 & 901.3886 & -0.2 \\
\hline$-\mathrm{H}_{2} \mathrm{O}$ & $\mathrm{C}_{43} \mathrm{H}_{63} \mathrm{O}_{17} \mathrm{~S}^{+}$ & 883.3756 & 883.3780 & -2.7 & $\mathrm{C}_{43} \mathrm{H}_{63} \mathrm{O}_{17} \mathrm{~S}^{+}$ & 883.3744 & 883.3780 & -4.1 \\
\hline \multirow[t]{7}{*}{$-\mathrm{OSO}_{3} \mathrm{H}$} & $\mathrm{C}_{43} \mathrm{H}_{63} \mathrm{O}_{14}{ }^{+}$ & 803.4182 & 803.4212 & -3.7 & $\mathrm{C}_{43} \mathrm{H}_{63} \mathrm{O}_{14}{ }^{+}$ & 803.4173 & 803.4212 & -4.9 \\
\hline & $\mathrm{C}_{15} \mathrm{H}_{21} \mathrm{O}_{2}^{+}$ & 233.1533 & 233.1536 & -1.3 & $\mathrm{C}_{14} \mathrm{H}_{19} \mathrm{O}_{2}^{+}$ & 219.1375 & 219.1380 & -2.1 \\
\hline & $\mathrm{C}_{15} \mathrm{H}_{19} \mathrm{O}^{+}$ & 215.1429 & 215.1430 & -0.5 & $\mathrm{C}_{7} \mathrm{H}_{9} \mathrm{O}^{+}$ & 109.0644 & 109.0648 & -3.6 \\
\hline & $\mathrm{C}_{8} \mathrm{H}_{11} \mathrm{O}^{+}$ & 123.0800 & 123.0804 & -3.2 & $\mathrm{C}_{6} \mathrm{H}_{9}+$ & 81.0697 & 81.0699 & -2.2 \\
\hline & $\mathrm{C}_{7} \mathrm{H}_{9} \mathrm{O}^{+}$ & 109.0645 & 109.0648 & -2.8 & & & & \\
\hline & $\mathrm{C}_{7} \mathrm{H}_{11}{ }^{+}$ & 95.0852 & 95.0855 & -3.2 & & & & \\
\hline & $\mathrm{C}_{6} \mathrm{H}_{9}{ }^{+}$ & 81.0696 & 81.0699 & -3.7 & & & & \\
\hline
\end{tabular}

Positive mode ESI ${ }^{+}$-targeted MS/MS of MTX3 and gambierone molecular ion $[\mathrm{M}+\mathrm{H}]^{+}, m / z 1039.4931$ and $\mathrm{m} / \mathrm{z} 1025.4774$, respectively, at an average $\mathrm{CE}$ of 20,40 and $60 \mathrm{eV}$ allowed for the unambiguously confirmation of both compounds. MTX3-targeted MS/MS spectra showed a series of: 1) water losses and sulfite loss plus water losses ( $\Delta \mathrm{ppm}<4 \mathrm{ppm}), 2$ ) the ion with theoretical $\mathrm{m} / \mathrm{z} 803.4212$ also common to gambierone, and 3) the ions corresponding to those already reported in LC-MS/MS at $\mathrm{m} / z 233.1553$ $(\Delta \mathrm{ppm}=-1.3 \mathrm{ppm})$ and $\mathrm{m} / \mathrm{z} 109.0645(\Delta \mathrm{ppm}=-2.8 \mathrm{ppm})$, assigned to the fragmentation of MTX3 I-ring (Figure 3A) (Table 3). 

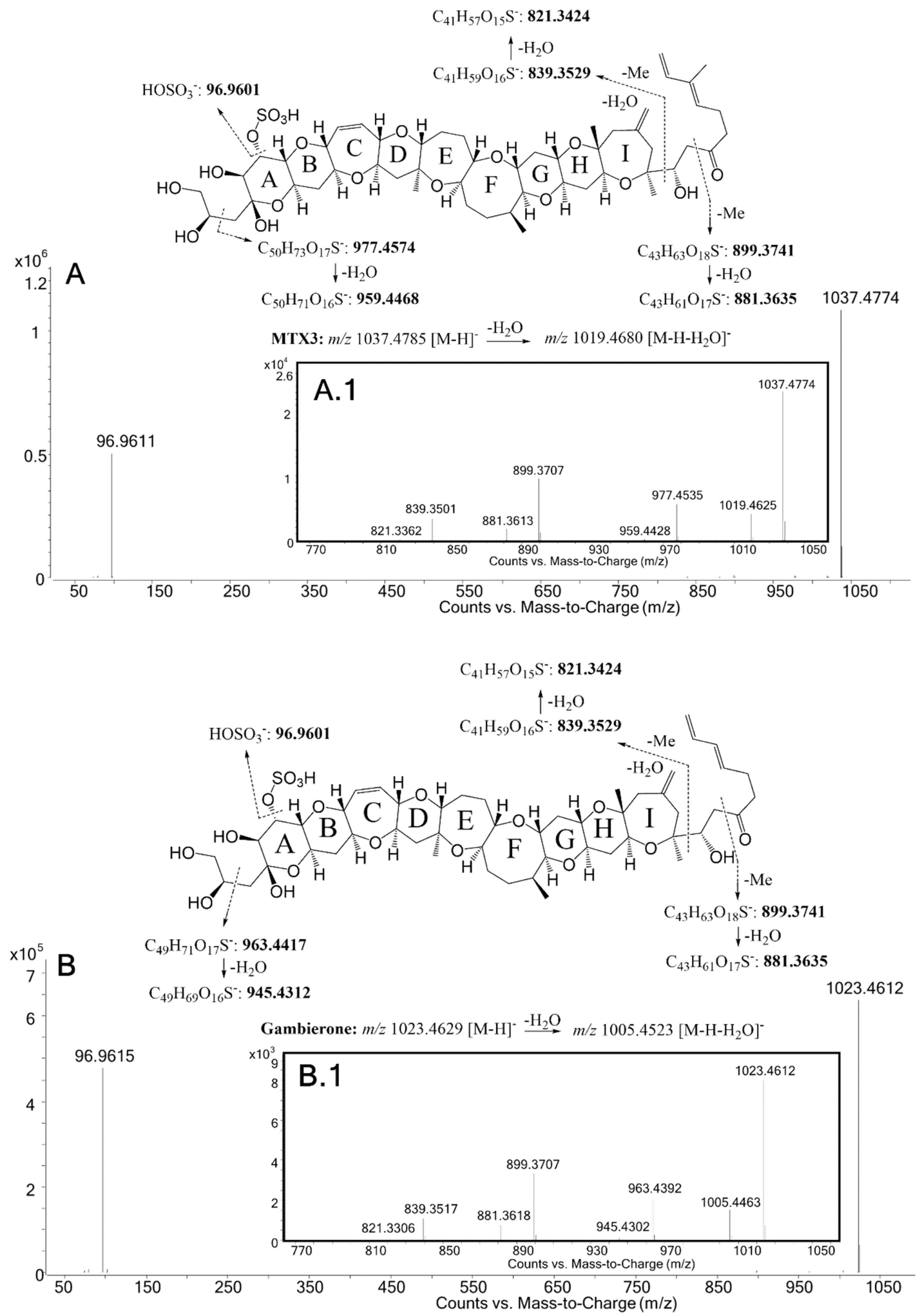

Figure 2. ESI-targeted HRMS/MS spectra of: MTX3 in G. australes: (A) average CE of $30 \mathrm{eV}, 50$ and $70 \mathrm{eV}$; (A1) zoom from $\mathrm{m} / \mathrm{z} 770$ to $\mathrm{m} / \mathrm{z} 1050$ at $70 \mathrm{eV}$, gambierone in Gambierdiscus sp.2; (B) average CE of $30 \mathrm{eV}, 50$ and $70 \mathrm{eV}$; (B1) zoom from $\mathrm{m} / \mathrm{z} 770$ to $\mathrm{m} / \mathrm{z} 1050$ at $70 \mathrm{eV}$. 

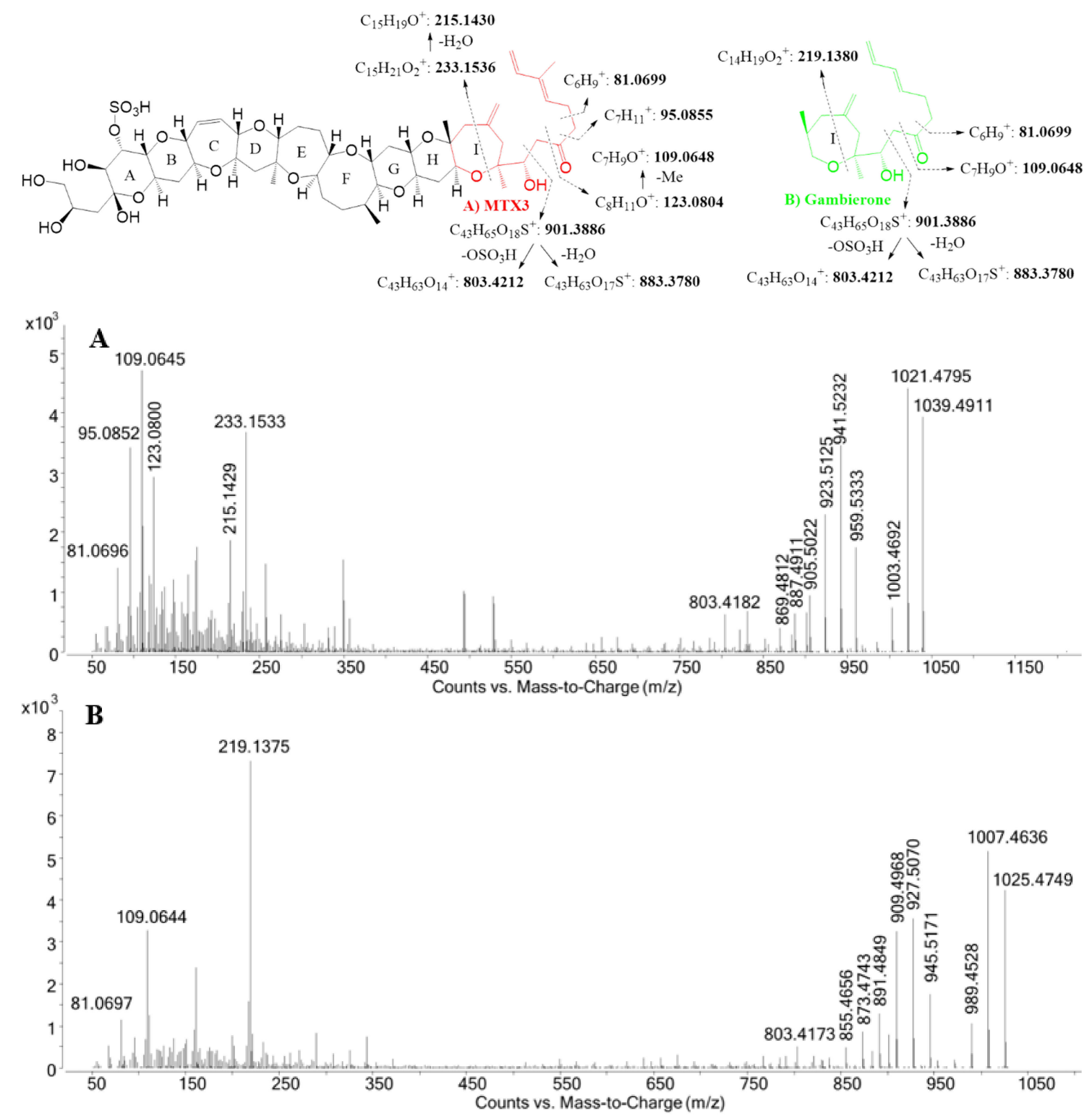

Figure 3. +ESI averaged $20 \mathrm{eV}, 40 \mathrm{eV}$ and $60 \mathrm{eV}$ and targeted HRMS/MS spectra of: (A) MTX3 in G. australes, (B) gambierone in Gambierdiscus. sp.2.

The same fragmentation pattern was observed for gambierone with the detection of water losses and sulfite loss plus water losses $(\Delta \mathrm{ppm}<5 \mathrm{ppm})$, the ion with $\mathrm{m} / z 803.4173(\Delta \mathrm{ppm}=-4.9 \mathrm{ppm})$, and the gambierone specific ions $\mathrm{m} / \mathrm{z} 219.1375(\Delta \mathrm{ppm}=-2.1 \mathrm{ppm})$ and $\mathrm{m} / \mathrm{z} 109.0644(\Delta \mathrm{ppm}=-3.6 \mathrm{ppm})$ (Figure 3B) (Table 3).

Due to the lack of the molecular formula of MTX4, its confirmation in the G. excentricus from the Canary Islands (Spain) could not be carried out by screening with the database. However, the availability of MTX4 reference material allowed for confirmation of this compound by comparing retention time (7.5 min), as well as further $\mathrm{ESI}^{-}$-targeted MS/MS by selecting the $[\mathrm{M}-2 \mathrm{H}]^{2-}$ and detection of the two fragment ions $\left[\mathrm{HOSO}_{3}\right]^{-}$and $\left[\mathrm{SO}_{3}\right]^{-}$(Figure 4).

The putative gambierone analogue detected by LC-MS/MS was identified by LC-HRMS ESI ${ }^{+}$full scan analysis using the algorithm Find-By-Molecular-Feature (FBF) to detect, at a retention time of $6.0 \mathrm{~min}$, a prominent ion with $\mathrm{m} / \mathrm{z} 1042.4911$ assigned to $\left[\mathrm{M}+\mathrm{NH}_{4}\right]^{+}$as well as $[\mathrm{M}+\mathrm{H}]^{+} \mathrm{m} / \mathrm{z} 1025.4632$, $[\mathrm{M}+\mathrm{Na}]^{+} \mathrm{m} / \mathrm{z} 1047.4427$ and $[\mathrm{M}+\mathrm{K}]^{+} \mathrm{m} / \mathrm{z} 1063.4108$ (Figure S3). The mass differences $(\Delta \mathrm{ppm}$ ) for these ions were higher than 13 , indicating that this compound is probably not a gambierone isomer (Table S3, 
Figure S3). It was also observed that under the LC-HRMS conditions the ion pattern of this compound is different to both gambierone and the putative gambierone analogue in low- and high-resolution MS, where the prominent ion is the protonated molecule $[\mathrm{M}+\mathrm{H}]^{+} . \mathrm{ESI}^{-}$-targeted MS/MS of the $[\mathrm{M}-\mathrm{H}]^{-}$of the putative gambierone revealed a hydrogenated sulfate anion loss typical of MTX-like compounds, whereas no specific or common fragments to gambierone or MTX3 were detected between $m / z 770$ and $m / z 1010$ (Figure S4). Positive ionization mode targeted MS/MS of the $[\mathrm{M}+\mathrm{H}]^{+}$also revealed a similar fragmentation pattern as gambierone and MTX3 with sulfate loss plus water losses, however, large mass differences $(\Delta \mathrm{ppm}>20)$ were observed compared to gambierone and no fragments common to gambierone were detected (Table S4 and Figure S5).

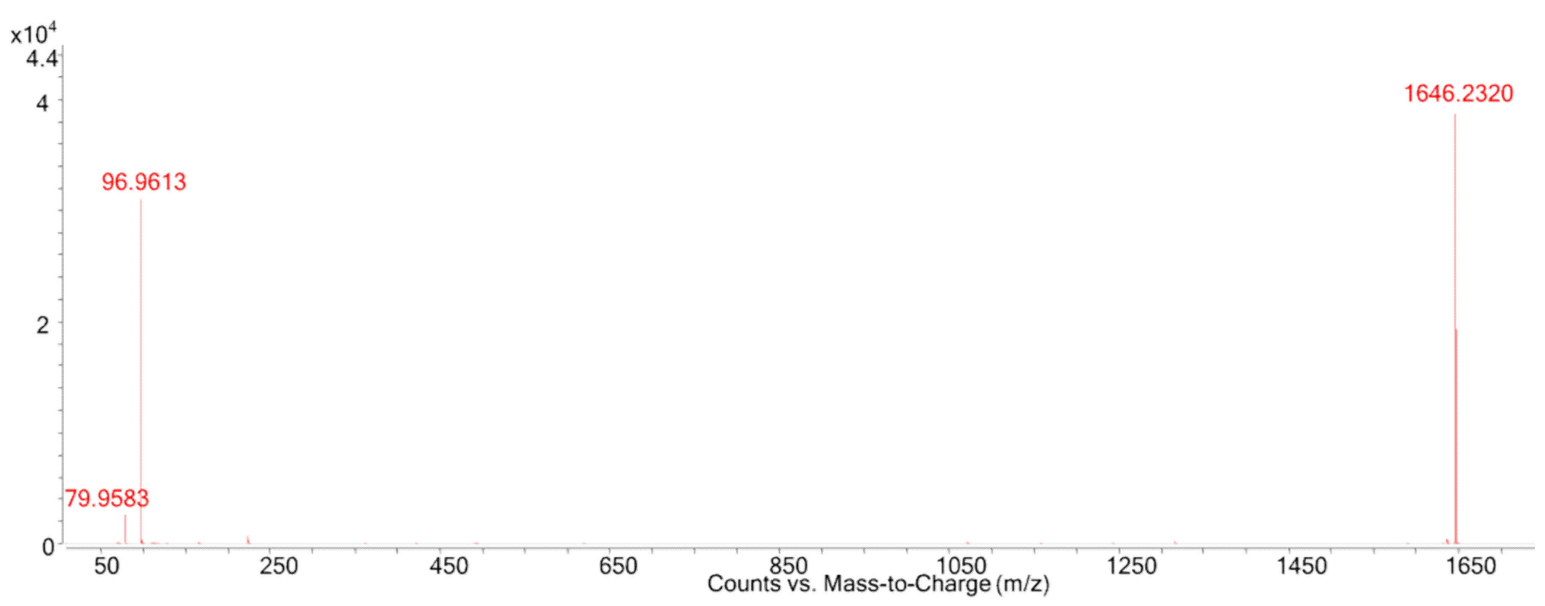

Figure 4. $\mathrm{ESI}^{-}$-targeted HRMS/MS spectra at $110 \mathrm{eV}$ of MTX4 from G. excentricus extract.

The screening of raw data with the database of the $\mathrm{ESI}^{-}$and $\mathrm{ESI}^{+}$full scan data also detected a putative gambieroxide at a retention time of $5.3 \mathrm{~min}$ in the MSF of all G. australes strains (Table S5). Negative ESI full scan mode allowed for detection of the deprotonated molecule $[\mathrm{M}-\mathrm{H}]^{-}$of the putative gambieroxide with $\Delta \mathrm{ppm}<3 \mathrm{ppm}$ (Figure S6). Positive ESI full scan acquisition showed a prominent ion at $\mathrm{m} / \mathrm{z} 1212.6019$ corresponding to $\left[\mathrm{M}+\mathrm{NH}_{4}\right]^{+}$with $\Delta \mathrm{ppm}=+3.0 \mathrm{ppm}$, and $[\mathrm{M}+\mathrm{Na}]^{+}$ was also detected at $m / z 1217.5553$ but with lower intensity and a $\Delta$ ppm $=+1.2$ ppm (Figure S7). Negative ESI-targeted MS/MS of $[\mathrm{M}-\mathrm{H}]^{-} \mathrm{m} / \mathrm{z} 1193.5572$ of the putative gambieroxide only revealed a fragment at $\mathrm{m} / \mathrm{z} 453.1964$ which was not identified in the molecule [18], whereas ESI ${ }^{+}$-targeted MS/MS of $\left[\mathrm{M}+\mathrm{NH}_{4}\right]^{+} \mathrm{m} / z 1212.5983$ showed a prominent fragment at $\mathrm{m} / z 1159.5493$ corresponding to $\left[\mathrm{M}+\mathrm{H}-2 \mathrm{H}_{2} \mathrm{O}\right]^{+}(-1.1 \mathrm{ppm})$ and followed by six water loss molecules. The lack of authentic gambieroxide MS/MS data or standard limited the confirmation of this compound (Figures S8 and S9).

As above mentioned, the DSF was also analyzed and compared with the corresponding compounds reported in the literature. Two compounds matching gambieric acid C and D were identified in both the $\mathrm{ESI}^{+}$and $\mathrm{ESI}^{-} \mathrm{MS}$ full scan in $\mathrm{G}$. australes. These compounds partially coeluted on the $\mathrm{C}_{18}$-column with retention times of $8.895 \mathrm{~min}$ for the compound tentatively identified as gambieric acid $\mathrm{C}$ and $8.928 \mathrm{~min}$ for the compound tentatively identified as gambieric acid D.

For both putative gambieric acid $\mathrm{C}$ and $\mathrm{D}$, the deprotonated molecular cluster $[\mathrm{M}-\mathrm{H}]^{-}$was detected with $\Delta$ ppm $<2.5$ ppm in all samples of G. australes (Figures 5A1 and 5B1) (See Tables S6 and S7). Positive ESI full scan mode showed at the same retention time three prominent ions corresponding to the molecular ion $[\mathrm{M}+\mathrm{H}]^{+}$and also pseudo-molecular ions $\left[\mathrm{M}+\mathrm{NH}_{4}\right]^{+},[\mathrm{M}+\mathrm{Na}]^{+}$with $\Delta$ ppm $<5 \mathrm{ppm}$ in all ions of these samples (Figures 5A and 5B, Tables S6 and S7). 


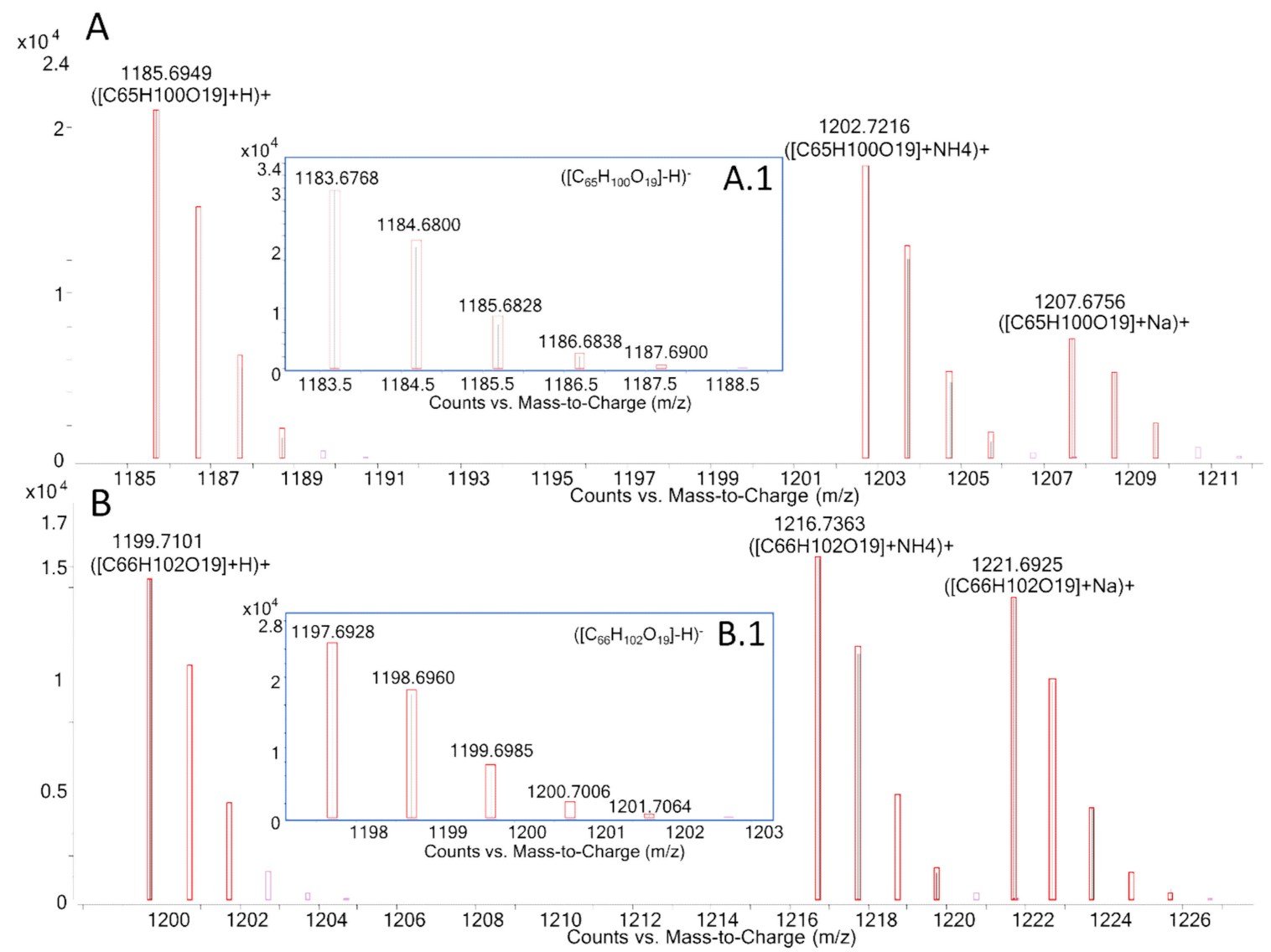

Figure 5. LC-HRMS full scan analysis of putative gambieric acid C, (A) $\mathrm{ESI}^{+}$, (A1) $\mathrm{ESI}^{-}$; putative gambieric acid D, (B) $\mathrm{ESI}^{+},(\mathbf{B 1}) \mathrm{ESI}^{-}$in G. australes extract.

Positive ESI-targeted MS/MS selecting gambieric acid C and D [M+H] $]^{+} \mathrm{m} / \mathrm{z} 1185.6932$ and $\mathrm{m} / \mathrm{z}$ 1199.7088 respectively, showing a common fragment with $\mathrm{m} / \mathrm{z} 135.1174$ assigned to the fragmentation of the side chain containing an ester group (Figure 6). Putative gambieric acid C spectra showed two prominent ions $\mathrm{m} / \mathrm{z} 1039.6331(\Delta \mathrm{ppm}=-2.0 \mathrm{ppm})$ and $\mathrm{m} / \mathrm{z} 943.5394(\Delta \mathrm{ppm}=-2.0 \mathrm{ppm})$, both followed by four water losses (Figure 6A). Putative gambieric acid D spectra showed a similar fragmentation pattern with the detection of $\mathrm{m} / \mathrm{z} 1053.6477(\Delta \mathrm{ppm}=-3.0 \mathrm{ppm})$ and $\mathrm{m} / \mathrm{z} 957.5542(\Delta \mathrm{ppm}=-2.9 \mathrm{ppm})$ both followed by water losses, with the most intense being the first water loss of both ions (Figure 6B).

$\mathrm{ESI}^{-}$-targeted MS/MS was also carried out by selecting the deprotonated molecular ions of putative gambieric acid $\mathrm{C}$ and $\mathrm{D}[\mathrm{M}-\mathrm{H}]^{-}, \mathrm{m} / \mathrm{z} 1183.6786$ and $\mathrm{m} / \mathrm{z} 1197.6943$, respectively. Despite the difficulty in fragmentation of the molecules in this ionization mode and the low abundance of the fragments, both compounds showed a similar fragmentation pattern, detecting a single water loss molecule $\left[\mathrm{M}-\mathrm{H}-\mathrm{H}_{2} \mathrm{O}\right]^{-} \mathrm{m} / \mathrm{z} 1165.6633(\Delta \mathrm{ppm}=-4.0 \mathrm{ppm})$ and $\mathrm{m} / \mathrm{z} 1179.6758(\Delta \mathrm{ppm}=-6.7 \mathrm{ppm})$, respectively, a fragment corresponding to cleavage on the alfa carbonyl group of the ester $m / z 1055.6275(\Delta \mathrm{ppm}$ $=-3.6 \mathrm{ppm})$ and $\mathrm{m} / \mathrm{z} 1069.6389(\Delta \mathrm{ppm}=-7.5 \mathrm{ppm})$ and a common fragment with $\mathrm{m} / \mathrm{z} 112.9852$ (Figure S10). 



Figure 6. $\mathrm{ESI}^{+}$-targeted HRMS/MS spectra at an average of 20, 40 and $60 \mathrm{eV}$ of (A) putative gambieric acid $C$ and (B) putative gambieric acid D; both detected in G. australes. 


\section{Discussion}

The present study identified and quantified compounds by LC-MS/MS and further confirmed via LC-HRMS the presence of maitotoxins as well as gambierone and other cyclic polyether compounds in dinoflagellates of the genus Gambierdiscus and Fukuyoa from the Mediterranean Sea and one G. excentricus from the Eastern Atlantic (Canary Islands, Spain).

LC-MS/MS negative ionization in MRM mode allowed for the sensitive quantitation of various MTXs. The two mono-sulfated MTXs recently isolated from Gambierdiscus of the Caribbean Sea, desulfo-MTX1 and didehydro-demethyl-desulfo-MTX1, were also monitored, assuming that due to their similarities to MTX1 they would have a similar fragmentation pattern monitoring $[\mathrm{M}-2 \mathrm{H}]^{2-} /[\mathrm{M}-2 \mathrm{H}]^{2-}$ as a quantitative transition and $[\mathrm{M}-2 \mathrm{H}]^{2-} /\left[\mathrm{HOSO}_{3}\right]^{-}$as qualitative transition. Quantitation of the different MTXs and gambierone was carried out using MTX1, the only commercially available maitotoxin. This quantitation may be most adequate for MTX4 which is a compound chemically similar to MTX1, not only in its molecular weight, but also in its fragmentation pattern. MTX3 (=44-methyl-gambierone) and gambierone, which are one-third the molecular weight of MTX1 and MTX4, were also quantified using this approach as they also contain a sulfate group and with results comparable to a commercially available analogue. This approach is traceable but results in somewhat increased uncertainty on any estimated concentration of these compounds.

Among the dinoflagellate species analyzed in this study, G. australes appears to be the species that produces the widest variety of hitherto reported Gambierdiscus metabolites: MTX3, putative gambieric acids $C$ and $D$, a putative gambierone analogue and a putative gambieroxide. All G. australes strains analyzed were from the same geographical region, Mallorca and Menorca, which are located in the western Mediterranean (Balearic Islands, Spain). The detection of MTX3 in this species is in agreement with the strains of G. australes recently isolated from Raoul Island (New Zealand) [14]. No MTX1 was detected in any strain of G. australes from Balearic Islands while, in contrast, this compound was detected by LC-MS/MS with MTX3 in strains of the same species from Kochi (Japan) as well as Macaulay Island (New Zealand) [11,28].

The recovery of MTX3 from the DSF was 75\% which indicates that the liquid/liquid partition using aqueous $\mathrm{MeOH}$ and dichloromethane must be further optimized to quantitatively separate MTX3 from CTXs. This partition behavior also shows that MTX3 has a somewhat lipophilic character which may result in MTX3 being absorbed and accumulated as CTXs in fish and the human digestive system. A recent study showed the accumulation of MTX1 in carnivorous fish tissues (liver and muscles of snappers) after exposure to G. australes [29]. While MTX3 clearly has much lower CTX-like activity compared to CTX3C [13], MTX3 was detected in much higher concentrations, estimated up to $1662 \mathrm{pg}$ MTX1-equiv. cell ${ }^{-1}$, suggesting that MTX3 should be monitored in fish muscle in order to explore its possible role in $\mathrm{CP}$.

The absence of MTX1 and the detection of a putative gambierone analogue in all G. australes pointed out another possible difference in the toxin profiles of G. australes from the Mediterranean Sea and the Pacific Ocean. The use of LC-HRMS showed the ability to conclude that this compound, which initially seemed to be a gambierone isomer by full scan and MRM mode in LC-MS/MS, is not a gambierone isomer due to its high $\Delta \mathrm{ppm}$ compared to authentic gambierone. Toxicity of purified fractions containing this compound should be evaluated to check its possible interest for the overall assessment of the toxicity of G. australes.

Putative gambieric acids C and D were detected in the DSF of all strains of G. australes, but not in any other species. Again, this suggests a strong lipophilic character and the potential to accumulate in fish flesh and potentially pass through the human intestinal barrier. Despite the lack of reference material for gambieric acids $\mathrm{C}$ and D to compare retention time, the $\mathrm{HRMS} \mathrm{ESI}^{-}$and $\mathrm{ESI}^{+}$full scan and targeted MS/MS analysis showed confident data to conclude that the compounds detected should match these potent antifungal compounds, initially isolated from G. toxicus from French Polynesia in $1992[17,30]$, i.e., prior to this species being separated into several other species. Gambieric acid D was recently detected in the tissue of a shark involved in a $\mathrm{CP}$ in the Indian Ocean, suggesting the stability 
of some of these compounds through the food web [4]. The toxicity of gambieric acids C and D and their role in CP is not clear, the only toxicological data is in mouse lymphoma cells L5178Y showing a moderately low toxic effect $[17,30]$.

Despite the detection of a putative gambieroxide in the MSF of all strains of G. australes by LC-HRMS, its confirmation is not conclusive due to the lack of authentic gambieroxide to compare retention time as well as fragmentation in targeted MS/MS. Gambieroxide was first isolated from the G. toxicus GTP2 strain collected at Papeete in French Polynesia and has a structure similar to yessotoxin [18].

The only F. paulensis analyzed in this work was also from Menorca (Balearic Islands, Spain) and showed a low amount of MTX3, $10.5 \mathrm{pg}$ MTX eq./cell, which may explain the poor recovery of $18 \%$ from the MSF, reinforcing the inadequacy of this liquid/liquid partition for this particular compound. MTX3 was also detected by LC-MS/MS in F. paulensis from Australia and New Zealand [31,32]. In the Western Mediterranean Sea (Formentera, Balearic Islands, Spain), a positive response was observed in the mouse bioassay (MBA) for both MSF and DSF of a F. paulensis and the inconclusive detection by LC-HRMS of gambieric acid A and 54-deoxy-CTX1B in trace levels [25].

Gambierdiscus sp.2 from Crete (Greece) showed a profile with low MTX3 concentration (4.2 pg MTX1-eq./cell) and gambierone at much higher concentration (776 pg MTX1-eq./cell). The biological activity of gambierone is similar to CTX3C but of lower potency (similar to MTX3) and since approximately $8 \%$ partitioned into the DSF, it should also be monitored in fish tissue from CP cases [15]. The presence of Gambierdiscus in Crete Island was first reported in 2003 by [24], while it was not until 2017 that a putative MTX3 was detected by LC-MS/MS in a G. carolinianus strain from this region [20].

The availability of a strain of G. excentricus from La Gomera (Canary Islands, Spain) allowed for confirmation that MTX4 is the main MTX present in this species as previously reported [11]. The liquid/liquid partitioning step appeared adequate for MTX4 as $99.3 \%$ of MTX4 were recovered in the MSF.

\section{Conclusions}

This study allowed for the characterization of the toxins produced by different species of dinoflagellates from the Mediterranean Sea. LC-MS/MS was used for a first and rapid screening, allowing a quantitative estimation of the toxins involved, while LC-HRMS allowed for their confirmation and characterization. Dinoflagellates from the Mediterranean Sea showed toxin profiles similar to those detected in CP endemic regions. Strains of G. australes from Mallorca and Menorca (Spain, Mediterranean Sea) produced MTX3, putative gambieric acid C and D, a putative gambierone analogue and putative gambieroxide, while MTX1 was absent in contrast to the same species from temperate waters of the Pacific Ocean. F. paulensis from the same region only produced MTX3, and the strain of Gambierdiscus sp. 2 from Crete (Greece) produced MTX3 and gambierone. Further research needs to be carried out in order to evaluate the possible presence of CTXs in fish from the Mediterranean Sea, considering that the presence of these dinoflagellates is associated with the production and accumulation of CTXs through the marine food web.

\section{Materials and Methods}

\subsection{Reference Toxins and Chemicals}

Maitotoxin-1 (MTX1) standard used for the LC-MS analysis was obtained from Wako Chemicals USA, Inc. (Richmond, VA, USA). MTX1 standard was dissolved in $\mathrm{MeOH}: \mathrm{H}_{2} \mathrm{O}(1: 1, \mathrm{v} / \mathrm{v})$ being the stock solution $10 \mu \mathrm{g} \cdot \mathrm{mL}^{-1}$. MTX4 qualitative laboratory reference material partially purified from Gambierdiscus excentricus was available from a previous study at the Phycotoxins Laboratory [11]. MTX3 and gambierone were identified as both compounds have identical retention times in our chromatography in both G. australes and G. belizeanus, the two species from which they have been originally isolated. MTX3 and gambierone qualitative laboratory reference material from G. australes 
and G. belizeanus was available at the Phycotoxins Laboratory [11]. HPLC-grade methanol and dichloromethane for extraction were purchased from Sigma Aldrich (Saint Quentin Fallavier, France). Milli-Q water was supplied by a Milli-Q integral 3 system (Millipore, Saint-Quentin-Yvelines, France). Water, acetonitrile, formic acid and ammonium formate used to prepare mobile phases were of LC-MS grade. All these chemicals were purchased from Sigma Aldrich (Saint Quentin Fallavier, France).

In order to carry out the toxicity evaluation by Neuro-2a, CTX1B was provided by Dr. Lewis, University of Queensland and was stored in absolute methanol at $-20^{\circ} \mathrm{C}$. Neuroblastoma murine cells were purchased in ATCC LGC standards (USA). Fetal bovine serum (FBS), L-glutamine solution, ouabain, veratridine, phosphate buffered saline (PBS), penicillin, streptomycin, RPMI-1640 medium, sodium pyruvate, thiazolyl blue tetrazolium bromide (MTT) were purchased from Merck KGaA (Darmstadt, Germany). Dimethyl sulfoxide (DMSO) and absolute methanol were purchased from Honeywell (Fürth, Germany) and from Chemlab (Zedelgem, Belgium), respectively. The incubator was purchased from Binder, Germany. The microplate reader KC4 was purchased from BIO-TEK Instruments, Inc.

\subsection{Gambierdiscus and Fukuyoa Strains}

All nine dinoflagellate extracts analyzed in this work were obtained from the collection of strains obtained in the EuroCigua project. All strains were cultivated at the IRTA laboratory (Tarragona, Spain) and the detailed information about these strains is shown in Table 4.

Table 4. Detailed information about the dinoflagellate extracts analyzed with the neuroblastoma cell-based assay.

\begin{tabular}{cccccc}
\hline Species & Strain Code & Location & $\begin{array}{c}\text { Number of } \\
\text { Cells } \\
\text { Extracted }\end{array}$ & $\begin{array}{c}\text { Volume of } \\
\text { Culture (L) }\end{array}$ & $\begin{array}{c}\text { CTX-like } \\
\text { (fg CTX1B } \\
\text { Equiv./Cell) }\end{array}$ \\
\hline G. australes & IRTA-SMM-17-189 & $\begin{array}{c}\text { Torret, Menorca, Balearic } \\
\text { Islands, Spain }\end{array}$ & 17134000 & 20 & $83 \pm 12^{\text {a }}$ \\
\hline G. australes & IRTA-SMM-17-162 & $\begin{array}{c}\text { St. Adeodat, Menorca, } \\
\text { Balearic Islands, Spain }\end{array}$ & 27811000 & 20 & $101 \pm 7.5$ \\
\hline G. australes & IRTA-SMM-17-164 & $\begin{array}{c}\text { St. Adeodat, Menorca, } \\
\text { Balearic Islands, Spain }\end{array}$ & 4257000 & 20 & $>62.5$ (NQ) \\
\hline G. australes & IRTA-SMM-17-271 & $\begin{array}{c}\text { Macarella, Menorca, } \\
\text { Balearic Islands, Spain }\end{array}$ & 14007000 & 20 & $271 \pm 29$ \\
\hline F. paulensis & IRTA-SMM-17-209 & $\begin{array}{c}\text { Sacaleta, Menorca, } \\
\text { Balearic Islands, Spain }\end{array}$ & 6964000 & 20 & $16 \pm 1.7^{\text {a }}$ \\
\hline G. australes & IRTA-SMM-17-253 & $\begin{array}{c}\text { Anguila, Menorca, } \\
\text { Balearic Islands, Spain }\end{array}$ & 13735000 & 20 & $164 \pm 16$ \\
\hline G. australes & IRTA-SMM-17-244 & $\begin{array}{c}\text { Camp de Mar, Mallorca, } \\
\text { Balearic Islands, Spain }\end{array}$ & 4121000 & 5 & $155 \pm 25$ \\
\hline Gambierdiscus sp.2 & 0010G-CR-CCAUTH & $\begin{array}{c}\text { Kolimpari, Crete, Greece } \\
\text { G. excentricus }\end{array}$ & IRTA-SMM-17-407 & $\begin{array}{c}\text { Playa de vueltas, La } \\
\text { Gomera, Canary Islands, } \\
\text { Spain }\end{array}$ & 6084000 \\
\hline
\end{tabular}

NQ: not quantifiable; ${ }^{\text {a }}$ CTX-like toxicity evaluated in [33].

Culturing, Harvesting, Toxin Extraction of Gambierdiscus and Fukuyoa, and N2a Assay

All strains were inoculated in 5 L of medium ES (Provasoli 1968, modified by Jorge Diogène) and salinity was adjusted to 36 in $8 \mathrm{~L}$ flat-bottom, round glass-flasks. Cultures were maintained in filtered air, and light turbulence (gentle bubbling) was supplied by an air-pump system. The initial concentration of dinoflagellates was between 25 and 50 cells $/ \mathrm{mL}$. Strains were incubated at $24 \pm 0.5^{\circ} \mathrm{C}$. The illumination was provided by fluorescent tubes with photon irradiance of $100 \mu \mathrm{mol} \mathrm{m}^{-2} \mathrm{~s}^{-1}$ under a 12:12 $\mathrm{h}$ L:D photoperiod. When cultures arrived at the late-exponential phase (after $20 \pm 3$ days), 
cultures were vigorously shaken and $15 \mathrm{~mL}$ aliquots were taken and fixed with Lugol's iodine solution $(3 \%)$ to estimate the cell concentration (cell $/ \mathrm{mL})$. Subsequently, the remaining volume of each strain was filtered and collected through a $10 \mu \mathrm{m}$ plankton net (Holmbladsvej, Denmark) in sterile $50 \mathrm{~mL}$ Falcon tubes and centrifuged at $4300 \mathrm{~g}$ for $20 \mathrm{~min}$ (Allegra X-15R, Beckman Coulter). Supernatants were discarded and micro-algal pellets of each strain were pooled in one $50 \mathrm{~mL}$ Falcon tube. Centrifugation was repeated and supernatants were discarded. Pellets were subsequently kept at $-20{ }^{\circ} \mathrm{C}$ with absolute methanol (10 mL for $10^{6}$ cells) until toxin extraction. To extract the toxin from micro-algal pellets, each pellet in methanol was sonicated using an ultrasonic cell disrupter (Watt ultrasonic processor VCX750, USA). The tip amplitude was set at $37 \% 3 \mathrm{sec}$ on $/ 3 \mathrm{sec}$ off for $15 \mathrm{~min}$. The sample was then centrifuged at $600 \mathrm{~g}$ for $5 \mathrm{~min}$ at $4{ }^{\circ} \mathrm{C}$. Supernatant was then transferred to a glass vial. The procedure was repeated twice, one with methanol and another with aqueous methanol (50:50; v:v) (10 mL for $10^{6}$ cells) and these were pooled. After that, the pool was evaporated to dryness with a rotary evaporator (Büchi Syncore, Switzerland) or dried under $\mathrm{N}_{2}$ gas (Turbovap, Caliper, Hopkinton, USA) at $40{ }^{\circ} \mathrm{C}$ and re-suspended in pure methanol. These extracts were filtered with PTFE filters $(0.2 \mu \mathrm{m})$ and stored at $-20{ }^{\circ} \mathrm{C}$.

The Neuro-2a assay was performed according to Reverté et al., (2018) [23].

\subsection{Sample Pretreatment}

The methanol extract from the cell pellet extraction was evaporated to dryness under $\mathrm{N}_{2}$ stream at $50{ }^{\circ} \mathrm{C}$ and CTX- and MTX-like compounds were partitioned as previously described [11]. Briefly, the residue from extraction was reconstituted in dichloromethane $(50 \mathrm{~mL} / 1 \mathrm{million}$ cells $)$ and partitioned twice with $\mathrm{MeOH}: \mathrm{H}_{2} \mathrm{O}(3: 2, \mathrm{v} / \mathrm{v})(25 \mathrm{~mL} / 1$ million cells). Both organic and aqueous layers were evaporated to dryness under $\mathrm{N}_{2}$ stream at $50{ }^{\circ} \mathrm{C}$ and kept at $-20^{\circ} \mathrm{C}$ prior to the analysis. MTX-like compounds were supposed to partition into the $\mathrm{MeOH}: \mathrm{H}_{2} \mathrm{O}(3: 2, \mathrm{v} / \mathrm{v})$, whereas CTX-like compounds were supposed to partition into the dichloromethane layer. Dried residue from the aqueous methanol fraction was reconstituted in $0.5 \mathrm{~mL}$ of $\mathrm{MeOH}: \mathrm{H}_{2} \mathrm{O}(1: 1, \mathrm{v} / \mathrm{v})$, whereas the solid residue from the dichloromethane layer was reconstituted in $0.5 \mathrm{~mL} \mathrm{MeOH}$, with both being filtrated through $0.22 \mu \mathrm{m}$ prior to the LC-MS analysis.

\subsection{LC-MS Analysis}

\subsubsection{LC-MS/MS (API 4000 QTrap)}

LC-MS/MS analysis to monitor specific MTX congeners and gambierone was performed using an LC system (UFLC XR Nexera, Shimadzu, Japan) coupled to a hybrid triple quadrupole/ion-trap mass spectrometer API 4000 QTrap (SCIEX, Redwood City, CA, USA) equipped with a turboV ${ }^{\circledR}$ ESI source. Maitotoxins and gambierone were separated using a reversed-phase C18 Kinetex column (100 A, $2.6 \mu \mathrm{m}, 50 \times 2.1 \mathrm{~mm}$, Phenomenex, Le Pecq, France) with water (A) and 95\% acetonitrile/water (B), both containing $2 \mathrm{mM}$ of ammonium formate and $50 \mathrm{mM}$ of formic acid. The column oven and the sample tray temperatures were set at $40{ }^{\circ} \mathrm{C}$ and $4{ }^{\circ} \mathrm{C}$, respectively. The flow rate was set at $0.4 \mathrm{~mL}$ $\min ^{-1}$ and the injection volume was set to $5 \mu \mathrm{L}$. Separation was achieved using the following mobile phase gradient: from $10 \%$ to $95 \%$ B in $10 \mathrm{~min}$, keep at $95 \%$ B for 2 min, return to $10 \%$ B in 0.1 min and equilibration for $3.9 \mathrm{~min}$ prior the next injection. The instrument control, data processing and analysis were conducted using Analyst software 1.6.3 (Sciex, Redwood city, CA, USA). LC-MS/MS analyses were carried out in negative ion acquisition mode, monitoring the transitions shown in Table S5 in Multiple Reaction Monitoring (MRM) mode with a dwell time of 80 ms Retention time of the different compounds with reference material available are shown in Table S8. Source conditions were curtain gas 25 psi, ionspray $-4.5 \mathrm{kV}$, turbogas temperature of $500{ }^{\circ} \mathrm{C}$, gas 1 and 2 set at 50 psi, and an entrance and declustering potential of $-10 \mathrm{~V}$ and $-210 \mathrm{~V}$, respectively. Positive ion acquisition mode was also used in the analysis of MTX3 and gambierone. Source conditions were curtain gas 25 psi, ionspray 
$4.5 \mathrm{kV}$, turbogas temperature of $500{ }^{\circ} \mathrm{C}$, gas 1 and 2 set at $50 \mathrm{psi}$, and an entrance and declustering potential of $10 \mathrm{~V}$ and $100 \mathrm{~V}$, respectively.

The fragment ion monitored in negative ionization mode for all the MRM transition of the MTX-group of toxins was the hydrogenated sulfate anion $\mathrm{m} / \mathrm{z} 96.9\left[\mathrm{HOSO}_{3}\right]^{-}$which was used as the confirmatory transition. Quantification of MTX1, MTX4, desulfo-MTX1 and didehydrodemethyl-desulfo-MTX1 was conducted using the MRM transition $[\mathrm{M}-2 \mathrm{H}]^{2-} /[\mathrm{M}-2 \mathrm{H}]^{2-}$ for MTX3 and gambierone $[\mathrm{M}-\mathrm{H}]^{-} /[\mathrm{M}-\mathrm{H}]^{-}$(Table S8). Due to the lack of the appropriate standards for the quantitation of each compound, MTX3, MTX4 and gambierone were quantified against the MTX1 calibration curve, assuming equal molar response and applying the same LOD and LOQ calculated for MTX1.

The MTX1 standard calibration range for the LC-MS/MS analysis consisted of seven concentrations ranging from 0.2 to $10 \mu \mathrm{g} \mathrm{mL} \mathrm{m}^{-1}$ in $\mathrm{MeOH}: \mathrm{H}_{2} \mathrm{O}(1: 1, \mathrm{v} / \mathrm{v})$. Limit of detection (LOD) and quantification (LOQ) were determined with the ordinary least-squares regression data method [34,35]. The LOD was calculated as three times the standard deviation of the y-intercepts over the slope of the calibration curve; the LOQ was calculated as 10 times the standard deviation of the $y$-intercepts over the slope of the calibration curve $[34,35]$. Therefore, LOD and LOQ for the MTX1 MRM transition $[\mathrm{M}-2 \mathrm{H}]^{2-} /[\mathrm{M}-2 \mathrm{H}]^{2-}$ were 0.32 and $0.97 \mu \mathrm{g} \mathrm{mL}^{-1}$, respectively.

\subsubsection{LC-HRMS and HRMS/MS (Q-Tof 6550 iFunnel)}

LC-HRMS analyses were carried out using a UHPLC system 1290 Infinity II (Agilent Technologies, Santa Clara, CA, USA) coupled to a HRMS time of flight mass spectrometer Q-Tof 6550 iFunnel (Agilent Technologies, Santa Clara, CA, USA). Chromatographic separation was performed using a Kinetex C18 column (100 ̊, $1.7 \mu \mathrm{m}, 100 \times 2.1 \mathrm{~mm}$, Phenomenex, Le Pecq, France) at $40{ }^{\circ} \mathrm{C}$ with water $(\mathrm{A})$ and $95 \%$ acetonitrile (B) both containing $2 \mathrm{mM}$ ammonium formate and $50 \mathrm{mM}$ formic acid. The flow rate was $0.4 \mathrm{~mL} \mathrm{~min}{ }^{-1}$ and the injection volume was $5 \mu \mathrm{L}$. Gradient of mobile phase was carried out as follows: $5 \%$ B was kept for $1 \mathrm{~min}$, then increased to $100 \%$ B over $11 \mathrm{~min}$, kept at $100 \%$ B for $2 \mathrm{~min}$ and returned to the initial conditions in $0.5 \mathrm{~min}$ and then equilibrated the column for $4.5 \mathrm{~min}$ prior to the next injection.

Source conditions were set as follows: gas temperature, $160{ }^{\circ} \mathrm{C}$; gas flow, $11 \mathrm{~L} / \mathrm{min}$; nebulizer, $45 \mathrm{psi}$; sheath gas temperature, $250^{\circ} \mathrm{C}$; sheath gas flow, $11 \mathrm{~L} / \mathrm{min}$; capillary voltage, $4500 \mathrm{~V}$ and nozzle voltage, $500 \mathrm{~V}$. The instrument was calibrated, using the Agilent tuning mix, in negative and positive ionization mode before each analysis.

LC-HRMS analyses were carried out in full scan and targeted MS/MS mode in positive and negative ionization mode in separate runs. Full scan analysis operated at a mass resolution of 40,000 Full width at Half Maximum (FWHM) over a mass-to-charge ratio $(\mathrm{m} / \mathrm{z})$ ranging from 100 to 3200 with a scan rate of 1 spectra/s. Targeted MS/MS was performed in a Collision Induced Dissociation (CID) cell at 45,000 FWHM over the scan rage from m/z 50 to 1700 with a scan rate of 10 spectra/s and a scan rate of 3 spectra/s applying three different collision energies in order to have a good fragmentation pathway. Two reference masses $\mathrm{m} / \mathrm{z} 121.0509$ (purine) and $\mathrm{m} / \mathrm{z} 922.0099$ (hexakisphosphazine) were continuously monitored during the entire run. Data acquisition was controlled by MassHunter software (Agilent technologies, CA, USA). Raw data were processed with Agilent MassHunter Qualitative Analysis software (version B.07.00, service pack 1) using the Find by Formula $(\mathrm{FbF})$ algorithm screening with a Personal Compound Database and Library (PDCL) created by Phycotoxins laboratory (IFREMER, France).

Supplementary Materials: The following are available online at http://www.mdpi.com/2072-6651/12/5/305/s1, Figure S1. LC-MS/MS Full scan analysis of: A) MTX3 from G. australes; B) gambierone from Gambierdiscus sp; C) putative gambierone analogue from G. australes, Figure S2. LC-MS/MS spectra resulting from enhanced product ion scan at an average CE of 20, 40 and $60 \mathrm{eV}$ of: A) MTX3 from G. australes; B) gambierone from Gambierdiscus sp; C) putative gambierone analogue from G. australes, Table S1. Accurate mass measurements using LC-HRMS full scan analysis in ESI ${ }^{-}$and ESI ${ }^{+}$mode for MTX3, Table S2. Accurate mass measurements using LC-HRMS full scan analysis in $\mathrm{ESI}^{-}$and $\mathrm{ESI}^{+}$mode for gambierone, Figure S3. Putative gambierone analogue detected in LC-HRMS 
using the Find by Molecular Feature (FMF) algorithm in G. australes at $6.08 \mathrm{~min}$, Table S3. $\mathrm{m} / z$ measured values for the putative gambierone analogue and $\Delta \mathrm{ppm}$ calculated in base of gambierone theoretical values, Figure S4. ESI $^{-}$-targeted MS/MS analysis of the putative gambierone analogue selecting $[\mathrm{M}-\mathrm{H}]^{-}$ion in G. australes at $6.08 \mathrm{~min} . \mathrm{m} / \mathrm{z}$ measured values for the putative gambierone analogue and $\Delta \mathrm{ppm}$ calculated in base of gambierone theoretical values, Figure S5. ESI ${ }^{+}$-targeted MS/MS analysis of the putative gambierone analogue selecting $[\mathrm{M}+\mathrm{H}]^{+}$ ion in G. australes at $6.08 \mathrm{~min}$, Table S4. Accurate mass measurements for the putative gambierone analogue and $\Delta$ ppm calculated in base of gambierone theoretical values, Table S5. Accurate mass measurements using LC-HRMS full scan analysis in $\mathrm{ESI}^{-}$and ESI ${ }^{+}$mode for putative gambieroxide, Figure S6. ESI ${ }^{-}$LC-HRMS full scan analysis of putative gambieroxide detected in G. australes at $5.32 \mathrm{~min}$, Figure S7. ESI ${ }^{+}$LC-HRMS full scan analysis of putative gambieroxide detected in G. australes at $5.32 \mathrm{~min}$, Figure S8. ESI ${ }^{-}$-targeted HRMS/MS spectrum of putative gambieroxide selecting $[\mathrm{M}-\mathrm{H}]^{-}$ion in G. australes at a collision energy of $50 \mathrm{eV}$, Figure S9. ESI ${ }^{+}$-targeted HRMS/MS spectrum of putative gambieroxide selecting $[\mathrm{M}+\mathrm{H}]^{+}$ion in $\mathrm{G}$. australes at a collision energy of $20 \mathrm{eV}$, Table S6. Accurate mass measurements using LC-HRMS full scan analysis in ESI ${ }^{-}$and $\mathrm{ESI}^{+}$mode for putative gambieric acid C, Table S7. Accurate mass measurements using LC-HRMS full scan analysis in ESI ${ }^{-}$and ESI mode for putative gambieric acid D, Figure S10. ESI ${ }^{-}$-targeted MS/MS spectra at an average of 20, 40 and $60 \mathrm{eV}$ of: A) gambieric acid C; B) gambieric acid D detected in G. australes, Table S8. MRM transitions monitored using the LC-MS API 4000 QTrap.

Author Contributions: Conceptualization, P.E., M.S., A.G.-M., J.D. and P.H.; methodology, P.E., M.S., A.T., M.R.-A.; investigation, P.E., A.T., M.R.-A., K.A. and M.S.; resources, A.G.-M., J.D. and P.H.; data curation, P.E., M.S.; writing —original draft preparation, P.E., MS. and P.H.; writing—review and editing, A.G.-M., J.M.L.-M., M.R.-A., J.D. and P.H.; supervision, J.M.L.-M., A.G.-M. and P.H.; project administration, A.G.-M. and P.H.; funding acquisition, A.G.-M., J.D. and P.H. All authors have read and agreed to the published version of the manuscript.

Funding: The authors acknowledge the financial support from the European Food Safety Authority (EFSA) through the EUROCIGUA project (GP/EFSA/AFSCO/2015/03). Pablo Estevez (P.E.) acknowledges the PhD fellowship from the Xunta de Galicia (Regional Government, Spain) under grant ED481A-2018/207. The authors also acknowledge support from CERCA Programme / Generalitat de Catalunya and A. Tudó acknowledges IRTA-URV-Santander for her Phd grant (2016 PMF-PIPF-74).

Acknowledgments: Authors acknowledge the support received form technical staff in the different institutions; special thanks also to Maria Rey for her contribution to the micrograph of G. australes.

Conflicts of Interest: The authors declare no conflict of interest. The funders had no role in the design of the study; in the collection, analyses, or interpretation of data; in the writing of the manuscript, or in the decision to publish the results.

\section{References}

1. Yasumoto, T. The chemistry and biological function of natural marine toxins. Chem. Rec. 2001, 1, $228-242$. [CrossRef] [PubMed]

2. Yasumoto, T.; Murata, M. Marine toxins. Chem. Rev. 1993, 93, 1897-1909. [CrossRef]

3. Oshiro, N.; Yogi, K.; Asato, S.; Sasaki, T.; Tamanaha, K.; Hirama, M.; Yasumoto, T.; Inafuku, Y. Ciguatera incidence and fish toxicity in Okinawa, Japan. Toxicon 2010, 56, 656-661. [CrossRef] [PubMed]

4. Diogène, J.; Reverté, L.; Rambla-Alegre, M.; Del Río, V.; De La Iglesia, P.; Campàs, M.; Palacios, O.; Flores, C.; Caixach, J.; Ralijaona, C.; et al. Identification of ciguatoxins in a shark involved in a fatal food poisoning in the Indian Ocean. Sci. Rep. 2017, 7, 8240. [CrossRef] [PubMed]

5. Estevez, P.; Castro, D.; Valtierra, A.P.; Leão-Martins, J.M.; Vilariño, O.; Diogène, J.; Gago-Martínez, A. An Attempt to Characterize the Ciguatoxin Profile in Seriola fasciata Causing Ciguatera Fish Poisoning in Macaronesia. Toxins 2019, 11, 221. [CrossRef]

6. Murray, J.S.; Boundy, M.J.; Selwood, A.I.; Harwood, T. Development of an LC-MS/MS method to simultaneously monitor maitotoxins and selected ciguatoxins in algal cultures and P-CTX-1B in fish. Harmful Algae 2018, 80, 80-87. [CrossRef]

7. Abraham, A.; Jester, E.L.; Granade, H.R.; Plakas, S.M.; Dickey, R.W. Caribbean ciguatoxin profile in raw and cooked fish implicated in ciguatera. Food Chem. 2012, 131, 192-198. [CrossRef]

8. Murata, M.; Naoki, H.; Matsunaga, S.; Satake, M.; Yasumoto, T. Structure and Partial Stereochemical Assignments for Maitotoxin, the Most Toxic and Largest Natural Non-Biopolymer. J. Am. Chem. Soc. 1994, 116, 7098-7107. [CrossRef]

9. Murata, M.; Yasumoto, T. The structure elucidation and biological activities of high molecular weight algal toxins: Maitotoxin, prymnesins and zooxanthellatoxins. Nat. Prod. Rep. 2000, 17, 293-314. [CrossRef]

10. Holmes, M.J.; Lewis, R.J. Purification and characterisation of large and small maitotoxins from cultured Gambierdiscus toxicus. Nat. Toxins 1994, 2, 64-72. [CrossRef] 
11. Pisapia, F.; Sibat, M.; Herrenknecht, C.; Lhaute, K.; Gaiani, G.; Ferron, P.-J.; Fessard, V.; Fraga, S.; Nascimento, S.M.; Litaker, R.W.; et al. Maitotoxin-4, a Novel MTX Analog Produced by Gambierdiscus excentricus. Mar. Drugs 2017, 15, 220. [CrossRef] [PubMed]

12. Mazzola, E.P.; Deeds, J.R.; Stutts, W.L.; Ridge, C.D.; Dickey, R.W.; White, K.D.; Williamson, R.T.; Martin, G.E. Elucidation and partial NMR assignment of monosulfated maitotoxins from the Caribbean. Toxicon 2019, 164, 44-50. [CrossRef] [PubMed]

13. Boente-Juncal, A.; Álvarez, M.; Antelo, Á.; Rodríguez, I.; Calabro, K.; Vale, C.; Thomas, O.P.; Botana, L.M. Structure Elucidation and Biological Evaluation of Maitotoxin-3, a Homologue of Gambierone, from Gambierdiscus belizeanus. Toxins 2019, 11, 79. [CrossRef] [PubMed]

14. Murray, J.S.; Selwood, A.; Harwood, D.T.; Van Ginkel, R.; Puddick, J.; Rhodes, L.L.; Rise, F.; Wilkins, A.L. 44-Methylgambierone, a new gambierone analogue isolated from Gambierdiscus australes. Tetrahedron Lett. 2019, 60, 621-625. [CrossRef]

15. Rodríguez, I.; Genta-Jouve, G.; Alfonso, C.; Calabro, K.; Alonso, E.; Sánchez, J.A.; Alfonso, A.; Thomas, O.P.; Botana, L.M. Gambierone, a Ladder-Shaped Polyether from the Dinoflagellate Gambierdiscus belizeanus. Org. Lett. 2015, 17, 2392-2395. [CrossRef]

16. Satake, M.; Murata, M.; Yasumoto, T. Gambierol: A new toxic polyether compound isolated from the marine dinoflagellate Gambierdiscus toxicus. J. Am. Chem. Soc. 1993, 115, 361-362. [CrossRef]

17. Nagai, H.; Torigoe, K.; Satake, M.; Murata, M.; Yasumoto, T.; Hirota, H. Gambieric acids: Unprecedented potent antifungal substances isolated from cultures of a marine dinoflagellate Gambierdiscus toxicus. J. Am. Chem. Soc. 1992, 114, 1102-1103. [CrossRef]

18. Watanabe, R.; Uchida, H.; Suzuki, T.; Matsushima, R.; Nagae, M.; Toyohara, Y.; Satake, M.; Oshima, Y.; Inoue, A.; Yasumoto, T. Gambieroxide, a novel epoxy polyether compound from the dinoflagellate Gambierdiscus toxicus GTP2 strain. Tetrahedron 2013, 69, 10299-10303. [CrossRef]

19. Litaker, R.W.; Vandersea, M.; Faust, M.A.; Kibler, S.; Nau, A.W.; Holland, W.C.; Chinain, M.; Holmes, M.J.; Tester, P.A. Global distribution of ciguatera causing dinoflagellates in the genus Gambierdiscus. Toxicon 2010, 56, 711-730. [CrossRef]

20. Pisapia, F.; Holland, W.C.; Hardison, D.R.; Litaker, R.W.; Fraga, S.; Nishimura, T.; Adachi, M.; Nguyen-Ngoc, L.; Séchet, V.; Amzil, Z.; et al. Toxicity screening of 13 Gambierdiscus strains using neuro-2a and erythrocyte lysis bioassays. Harmful Algae 2017, 63, 173-183. [CrossRef]

21. Fraga, S.; Rodríguez, F. Genus Gambierdiscus in the Canary Islands (NE Atlantic Ocean) with Description of Gambierdiscus silvae sp. nov., a New Potentially Toxic Epiphytic Benthic Dinoflagellate. Protist 2014, 165, 839-853. [CrossRef] [PubMed]

22. Rodríguez, F.; Fraga, S.; Ramilo, I.; Rial, P.; Figueroa, R.I.; Riobó, P.; Bravo, I. Canary Islands (NE Atlantic) as a biodiversity 'hotspot' of Gambierdiscus: Implications for future trends of ciguatera in the area. Harmful Algae 2017, 67, 131-143. [CrossRef] [PubMed]

23. Reverté, L.; Toldrà, A.; Andree, K.B.; Fraga, S.; De Falco, G.; Campàs, M.; Diogène, J. Assessment of cytotoxicity in ten strains of Gambierdiscus australes from Macaronesian Islands by neuro-2a cell-based assays. Environ. Boil. Fishes 2018, 30, 2447-2461. [CrossRef]

24. Aligizaki, K.; Nikolaidis, G. Morphological identification of two tropical dinoflagellates of the genera Gambierdiscus and Sinophysis in the Mediterranean Sea. J. Biol. Res. Thessaloniki 2008, 9, 75-82.

25. Laza-Martínez, A.; David, H.; Riobó, P.; Miguel, I.; Orive, E. Characterization of a Strain of Fukuyoa paulensis (Dinophyceae) from the Western Mediterranean Sea. J. Eukaryot. Microbiol. 2016, 63, 481-497. [CrossRef]

26. AECOSAN Website. Available online: http://www.aecosan.msssi.gob.es/AECOSAN/web/ciguatera/home/ aecosan_home_ciguatera.htm (accessed on 25 March 2020).

27. Lewis, R.J.; Holmes, M.J.; Alewood, P.F.; Jones, A. Lonspray mass spectrometry of ciguatoxin-1, maitotoxin-2 and -3 , and related marine polyether toxins. Nat. Toxins 1994, 2, 56-63. [CrossRef]

28. Rhodes, L.L.; Smith, K.F.; Murray, J.S.; Harwood, T.; Trnski, T.; Munday, R. The Epiphytic Genus Gambierdiscus (Dinophyceae) in the Kermadec Islands and Zealandia Regions of the Southwestern Pacific and the Associated Risk of Ciguatera Fish Poisoning. Mar. Drugs 2017, 15, 219. [CrossRef]

29. Kohli, G.S.; Papiol, G.G.; Rhodes, L.L.; Harwood, T.; Selwood, A.; Jerrett, A.R.; Murray, S.A.; Neilan, B.A. A feeding study to probe the uptake of Maitotoxin by snapper (Pagrus auratus). Harmful Algae 2014, 37, 125-132. [CrossRef] 
30. Nagai, H.; Murata, M.; Torigoe, K.; Satake, M.; Yasumoto, T. Gambieric acids, new potent antifungal substances with unprecedented polyether structures from a marine dinoflagellate Gambierdiscus toxicus. J. Org. Chem. 1992, 57, 5448-5453. [CrossRef]

31. Munday, R.; Murray, J.S.; Rhodes, L.L.; Larsson, M.E.; Harwood, T. Ciguatoxins and Maitotoxins in Extracts of Sixteen Gambierdiscus Isolates and One Fukuyoa Isolate from the South Pacific and Their Toxicity to Mice by Intraperitoneal and Oral Administration. Mar. Drugs 2017, 15, 208. [CrossRef]

32. Larsson, M.E.; Harwood, T.D.; Lewis, R.J.; Himaya, S.W.A.; Doblin, M.A. Toxicological characterization of Fukuyoa paulensis (Dinophyceae) from temperate Australia. Phycol. Res. 2018, 67, 65-71. [CrossRef]

33. Tudó, À.; Toldrà, A.; Rey, M.; Todolí, I.; Andree, K.B.; Fernández-Tejedor, M.; Campàs, M.; Sureda, F.X.; Diogène, J. Gambierdiscus and Fukuyoa as potential indicators of ciguatera risk in the Balearic Islands. Harmful Algae 2020, submitted.

34. Vial, J.; Jardy, A. Experimental Comparison of the Different Approaches To Estimate LOD and LOQ of an HPLC Method. Anal. Chem. 1999, 71, 2672-2677. [CrossRef]

35. Sanagi, M.M.; Ling, S.L.; Nasir, Z.; Hermawan, D.; Ibrahim, W.A.W.; Abu Naim, A. Comparison of Signal-to-Noise, Blank Determination, and Linear Regression Methods for the Estimation of Detection and Quantification Limits for Volatile Organic Compounds by Gas Chromatography. J. AOAC Int. 2009, 92, 1833-1838. [CrossRef] [PubMed]

(C) 2020 by the authors. Licensee MDPI, Basel, Switzerland. This article is an open access article distributed under the terms and conditions of the Creative Commons Attribution (CC BY) license (http://creativecommons.org/licenses/by/4.0/). 